\title{
Heavy minerals as provenance indicator in glaciogenic successions: An example from the Palaeozoic of Ethiopia
}

\author{
Anna Lewin ${ }^{\mathrm{a}}$, Guido Meinhold ${ }^{\mathrm{b}, \mathrm{c}}$, Matthias Hinderer ${ }^{\mathrm{a}}$, Enkurie L. Dawit ${ }^{\mathrm{d}}$, Robert Bussert ${ }^{\mathrm{e}}$, \\ Nils Keno Lünsdorf ${ }^{c}$ \\ ${ }^{a}$ Technische Universität Darmstadt, Material- und Geowissenschaften, Institut für \\ Angewandte Geowissenschaften, Schnittspahnstraße 9, 64287 Darmstadt, Germany; \\ alewin@geo.tu-darmstadt.de (AL), hinderer@geo.tu-darmstadt.de (MH) \\ ${ }^{\mathrm{b}}$ School of Geography, Geology and the Environment, Keele University, Keele, Staffordshire, \\ ST5 5BG, United Kingdom; g.meinhold@keele.ac.uk (GM)
}

${ }^{\mathrm{c}}$ Geowissenschaftliches Zentrum Göttingen, Abteilung Sedimentologie / Umweltgeologie, Universität Göttingen, Goldschmidtstraße 3, 37077 Göttingen, Germany; kluensd@gwdg.de (NKL)

${ }^{\mathrm{d} D e p a r t m e n t ~ o f ~ G e o l o g y, ~ U n i v e r s i t y ~ o f ~ G o n d a r, ~ P . O . ~ B o x ~ 196, ~ G o n d a r, ~ E t h i o p i a ; ~}$ dawit_leb@yahoo.de (ELD)

${ }^{\mathrm{e}}$ Institut für Angewandte Geowissenschaften, Technische Universität Berlin, Ernst-ReuterPlatz 1, 10587 Berlin, Germany; r.bussert@tu-berlin.de (RB)

Correspondence: Anna Lewin (alewin@geo.tu-darmstadt.de)

\begin{abstract}
We use heavy minerals and rutile and garnet chemical compositions to constrain the provenance of two glaciogenic sandstone formations that build up the Palaeozoic succession in Ethiopia. The heavy mineral assemblage of the Upper Ordovician-Lower Silurian Enticho Sandstone is dominated by ultra-stable minerals, implying high maturity of the sediment. Variable amounts of garnet are present as well. The Carboniferous-Permian Edaga Arbi Glacials contain mainly less stable heavy minerals, such as garnet and apatite, suggesting little chemical alteration. A combination of magmatic and metamorphic source rocks is likely for both formations. Rutile and garnet chemistry point to mainly amphibolite-facies and to a lesser extent granulite-facies metamorphic source rocks with generally slightly higher metamorphic temperatures for detrital heavy minerals in the Enticho Sandstone. We conclude that the Enticho Sandstone is mainly the product of reworked mature Cambrian-Ordovician sediment, which may have been supplied via the Gondwana super-fan system. Locally, glaciers of the Late Ordovician glaciation eroded fresh basement material, delivering the garnet. For the Edaga Arbi Glacials, a rather proximal provenance is likely. The potential source area is the southern hinterland, where Precambrian low- to higher grade metamorphic rocks of the Arabian-Nubian Shield occur at the transition to the Mozambique Belt.
\end{abstract}

Keywords: Ethiopia, Palaeozoic, provenance analysis, heavy minerals, rutile, garnet

\section{Introduction}

Two glaciations affected the super-continent Gondwana in the Palaeozoic: The Late Ordovician (Hirnantian) glaciation was short-lived and reconstructions propose a large ice sheet covering much of northern Gondwana (e.g. Eyles, 1993; Ghienne et al., 2007; Le Heron and Craig, 2008; Le Heron et al., 2018). The Late Palaeozoic Ice Age (LPIA) affected 
Ethiopia in the Carboniferous-Permian (Bussert and Schrank, 2007) and is considered more complex in its spatial and temporal extend (e.g. Eyles, 1993; Fielding et al., 2008). The Palaeozoic sedimentary succession in Ethiopia is the product of these two glaciations and comprises the Upper Ordovician-Lower Silurian Enticho Sandstone and the CarboniferousPermian Edaga Arbi Glacials. Sedimentological and palynological studies of the two formations by Dow et al. (1971), Beyth (1972a, b), Saxena and Assefa (1983), Bussert and Schrank (2007), Bussert and Dawit (2009) and Bussert (2010, 2014) provide stratigraphic control and evidence that two different glaciations are recorded.

Petrographic and bulk geochemical analyses (Lewin et al., 2018) reveal a very high mineralogical maturity for the Enticho Sandstone, which is striking for glaciogenic sediments. In contrast, the Edaga Arbi Glacials are less mature and more variable in composition. These trends have also been observed in age-equivalent formations in Saudi Arabia (Keller et al., 2011; Bassis et al., 2016a). In the Lower Palaeozoic, high maturity is a common feature of sandstones in northern Gondwana (Garfunkel, 2002; Avigad et al., 2005; Morag et al., 2011). The high similarity of Lower Palaeozoic sedimentary rocks across Gondwana, not only in maturity, but also in their detrital zircon age spectra, led Squire et al. (2006) to propose a model of large sediment fans that transported masses of detritus from the East African Orogen in the centre of Gondwana (Fig. 1) towards the continental margins. The long transport, possibly in combination with strong chemical weathering under a corrosive CambrianOrdovician atmosphere, may have led to the high maturity (Avigad et al., 2005; Morag et al., 2011). The super-fan hypothesis was confirmed for northern Gondwana by Meinhold et al. (2013) and Stephan et al. (2019). Detrital zircon ages in the Enticho Sandstone in Ethiopia are very similar to those of the presumed super-fan sediments, suggesting that the formation contains reworked super-fan material (Lewin et al., 2020).

For the Edaga Arbi Glacials, the low maturity and zircon ages similar to those in the ArabianNubian Shield make a local provenance likely (Lewin et al., 2018; Lewin et al., 2020). A reorganisation of the sediment dispersal system during the Carboniferous is also inferred for southern Libya (Morton et al., 2011) and Saudi Arabia (Knox et al., 2007; Bassis et al., 2016b) based on changes in the heavy mineral spectra. Heavy mineral data for the Ethiopian Palaeozoic sandstones are missing so far.

Heavy minerals in sediments and sedimentary rocks are widely used to infer the sediments' provenance by assigning the minerals and their parageneses to certain source rock lithologies, for which they are characteristic. Because the heavy mineral assemblage in a sediment is not only influenced by source rock lithology, but also by processes operating during weathering, transport, deposition and diagenesis (e.g. Morton and Hallsworth, 1994), single grain geochemical analyses on specific mineral species are a powerful complementary technique (von Eynatten and Dunkl, 2012). Rutile is one of the ultra-stable heavy minerals and very resistant to physical and chemical alterations. Furthermore, its trace element composition is dependent on the metamorphic temperature conditions during growth and the lithology of the host rock, making it a good candidate for provenance studies (e.g. Triebold et al., 2007; Meinhold, 2010; Triebold et al., 2012). Similarly, garnet composition depends on host rock lithology and pressure and temperature conditions during growth and its use in provenance analysis is well established (e.g. Morton, 1987; Mange and Morton, 2007; Krippner et al., 2014; Stutenbecker et al., 2017).

In this study we use the heavy mineral assemblages and rutile and garnet chemistry to further constrain the provenance of the two Palaeozoic sandstone formations in Ethiopia. This study 
tests the assumption that the Enticho Sandstone contains reworked material from the Gondwana super-fan system and that the Edaga Arbi Glacials originate from proximal source areas in the Arabian-Nubian Shield. We also examine whether a regional correlation of changes in the heavy mineral spectra from early to late Palaeozoic with sedimentary rocks in Libya and Saudi Arabia is possible. This allows a better understanding of the Palaeozoic sediment dispersal system of northern Gondwana and the influence of the two glaciations.

\section{Geological setting}

Both the Upper Ordovician-Lower Silurian Enticho Sandstone and the CarboniferousPermian Edaga Arbi Glacials are exposed around the Mekelle Basin in the northern Ethiopian province Tigray (Kazmin, 1972; Garland et al., 1978; Tsige and Hailu, 2007; Fig. 2). The Enticho Sandstone lies unconformably on the Neoproterozoic metamorphic basement. In some areas, also the Edaga Arbi Glacials lie unconformably on the Neoproterozoic basement while in others on the Enticho Sandstone. Both the Enticho Sandstone and the Edaga Arbi Glacials and are overlain by Mesozoic sediments (Beyth, 1972b; Tefera et al., 1996; Dawit, 2010; Fig. 2). In addition, glacial sediments corresponding to the Edaga Arbi Glacials occur in the Blue Nile region in western Ethiopia (Fig. 2b).

The basement in Ethiopia is part of the East African Orogen, comprising the Arabian-Nubian Shield in the north and the Mozambique Belt in the south (Kazmin et al., 1978; Tefera et al., 1996; Stern et al., 2012; Fig. 1). The Arabian-Nubian Shield is composed of mainly juvenile Neoproterozoic crust, which experienced greenschist- to amphibolite-facies metamorphism (e.g. Johnson et al., 2011). In the Mozambique Belt, amphibolite- to granulite-facies metamorphic grades can be found, ascribed to the intense Ediacaran collision between East and West Gondwana (Stern et al., 2012). The basement of northern Ethiopia is considered to belong to the Arabian-Nubian Shield (e.g. Stern et al., 2012; Johnson, 2014). The upper Tonian Tsaliet Group consists of effusive flows and diverse volcaniclastic rocks (Beyth, 1972b; Miller et al., 2009). The Cryogenian Tambien Group is made of marine siliciclastic and carbonate rocks deposited in post-magmatism basins (Alene et al., 2006; Avigad et al., 2007; Miller et al., 2009). Both units were metamorphically overprinted to greenschist-facies grade and syn- and post-tectonic granitoids and diorites intruded (Beyth, 1972b; Kazmin et al., 1978; Tefera et al., 1996). The Western and Southern Ethiopian Shields contain highgrade metamorphic rocks of the Mozambique Belt (Yibas et al., 2002; Woldemichael et al., 2010; Stern et al., 2012).

The Palaeozoic sedimentary succession starts with the Upper Ordovician-Lower Silurian Enticho Sandstone. Cambrian, Lower and Middle Ordovician sediments are missing. Body and trace fossils as well as palynoflora (cryptospores) constrain the age of the formation (Saxena and Assefa, 1983; Bussert and Dawit, 2009; Brocke et al., 2015); its thickness is up to $300 \mathrm{~m}$ (Saxena and Assefa, 1983; Dawit, 2010). The lower part is glaciogenic. Massive, large-scale trough or sigmoidal cross-bedded sandstones and conglomerates occur, which are interpreted as subaqueous meltwater deposits. Diamictite occurs in one location, which is probably a tillite. In the upper part of the Enticho Sandstone, well-sorted sandstones with bipolar cross-bed sets indicate a tidal deposition in a shallow sea (Bussert and Dawit, 2009; Dawit, 2010).

Between the Upper Ordovician-Lower Silurian Enticho Sandstone and the CarboniferousPermian Edaga Arbi Glacials there is a long hiatus; Middle Silurian to Middle Carboniferous rocks are not preserved. The Edaga Arbi Glacials have a thickness of up to $200 \mathrm{~m}$ in northern Ethiopia (Bussert, 2010) and lie unconformably either on the Enticho Sandstone or directly on 
the basement (e.g. Beyth, 1972b). They are biostratigraphically constrained by their wellpreserved microfloral assemblage (Bussert and Schrank, 2007). At the base, a polymict conglomerate probably represents a tillite; it is followed by laminated claystones and siltstones with scattered out-sized clasts and lenses of sandstone, interpreted as suspension settle-outs in a pro-glacial lake or fjord-like environment, with periodic hyperpycnal sediment flows and the deposition of dropstones (Beyth, 1972b; Bussert and Dawit, 2009; Bussert, 2014). For a more detailed facies description of the two studied formations and field photographs we refer to Bussert and Dawit (2009), Bussert (2014) and Lewin et al. (2018).

\section{Sampling and methods}

The selection of sampling sites was based on previous stratigraphic and sedimentological work and priority was given to sections that are biostratigraphically constrained (Bussert and Schrank, 2007; Bussert and Dawit, 2009; Brocke et al., 2015). In other sections, the assignment to one of the two formations was through lithofacies characteristics in the field and could be confirmed by geochemical analyses (Lewin et al., 2018; Table 1). Only one sample (Eda-5) was erroneously classified in the field and could be assigned to the Enticho Sandstone by bulk geochemistry. We chose 20 samples from the Enticho Sandstone and 11 samples from the Edaga Arbi Glacials for heavy mineral analysis (Table 1). The selection was made to cover a large spatial and stratigraphic range.

Approximately $1 \mathrm{~kg}$ of sample material was disaggregated using a jaw crusher followed by mortar and pestle. The material was treated with $10 \%$ acetic acid to dissolve carbonate, which was found in many samples as cement, especially in the Edaga Arbi Glacials. Furthermore, a mixture of sodium citrate, sodium bicarbonate and sodium dithionite $(60 \mathrm{~g}, 8 \mathrm{~g}$ and $20 \mathrm{~g}$, respectively, in $1 \mathrm{~L}$ of water) was used to remove iron oxide coating, which was especially strong in samples of the Enticho Sandstone. After being placed in an ultrasonic bath for five minutes, the samples were wet sieved to obtain the grain size fractions $40-63 \mu \mathrm{m}, 63-125 \mu \mathrm{m}$ and $125-500 \mu \mathrm{m}$. For further analyses, we focused on the grain size interval of $63-125 \mu \mathrm{m}$ to ensure comparability with corresponding data from previous studies in Libya (Morton et al., 2011) and Saudi Arabia (Bassis et al., 2016b). The other grain size intervals were additionally considered in four samples during conventional heavy mineral analysis to assess the influence of chosen grain size windows on the heavy mineral assemblage (Table S1). These samples were selected due to their relatively large grain size variation compared to the other samples and to cover a large geographical spread. Heavy mineral separation was done using sodium polytungstate with a density of $2.8 \mathrm{~g} / \mathrm{cm}^{3}$ in a separatory funnel. The separation procedure was performed two times per sample to ensure proper separation of the heavy and the light minerals.

\subsection{Conventional heavy mineral analysis}

For optical analysis of the heavy mineral assemblage, representative subsamples of the heavy mineral concentrates obtained with a micro-riffle splitter were mounted on glass slides embedded in Cargille Meltmount ${ }^{\mathrm{TM}}$ with a refraction index of 1.662. Mineral species were identified using a polarizing microscope and 200 translucent grains per sample were counted where possible. Since the grain size windows analysed are narrow, no area-sensitive counting method was used, and all grains encountered under the microscope were counted until 200 counts were reached. The proportions of translucent and opaque minerals were assessed based on 100 counts per sample.

\subsection{Raman spectroscopy}


To confirm the results from the optical analysis of the heavy mineral assemblages, we applied a semi-automatic identification and counting method based on Raman spectroscopy at the Geoscience Centre of the University of Göttingen (Lünsdorf et al., 2019) to 15 of the samples (Table 1, Table S1). The samples were chosen to cover all different minerals and assemblages identified during optical analysis. Representative subsamples of the respective heavy mineral concentrates were embedded in epoxy resin and polished to reveal the grains' interior on a flat surface. High-resolution mosaic images of the mounts were taken using a Zeiss Axio Imager M2m polarizing microscope with the ZEN Pro software at high magnification (50x, 0.75 NA) in transmitted and reflected light. Measuring spots were selected on these mosaics using the Coordsetter software introduced by Lünsdorf et al. (2019) and the coordinates were transferred to a Horiba Scientific XploRA PLUS Raman microscope. Raman spectroscopy was performed with a laser wavelength of $532 \mathrm{~nm}$, laser power of $25 \%$ (of $100 \mathrm{~mW}$ ) and circular polarization (lambda/4 retarder plate). The following measurement parameters were used; spectral grating: $1200 \mathrm{gr} / \mathrm{mm}$, spectrometer position: $1310 \mathrm{~cm}^{-1}$, objective: $50 \mathrm{x}, 0.5 \mathrm{NA}$, LWD, exposure time: $0.1 \mathrm{~s}$ (min.) $/ 30 \mathrm{~s}$ (max.), number of accumulations: 1 , max. intensity: 5000 cts. Automated identification of heavy mineral species was done with an in-house program using a modified version of the RRUFF database in combination with the segmental hit quality index approach (Lünsdorf et al., 2019). Depending on the quality of the mount and the proportions of translucent and opaque grains, between 87 and 937 translucent minerals per sample were confidently identified (Table S1).

\subsection{Electron microprobe analysis}

Rutile chemical analyses were performed on six samples from the Enticho Sandstone and four samples from the Edaga Arbi Glacials; garnet chemical analyses were performed on four samples from the Enticho Sandstone and five samples from the Edaga Arbi Glacials. The choice was made based on the amount of the respective mineral in the heavy mineral concentrate. Rutile and garnet grains were randomly handpicked under a binocular microscope from the heavy mineral concentrates of the $63-125 \mu \mathrm{m}$ grain size fraction, embedded in epoxy resin and polished to expose the grains' interior on a flat surface. The mounts were carbon-coated to ensure conductivity. Chemical analyses of the mineral grains were performed with a JEOL JXA 8900 RL electron microprobe equipped with five wavelength dispersive spectrometers at the Geoscience Centre of the University of Göttingen. Rutile was analysed with a beam current of $80 \mathrm{nA}$ and an accelerating voltage of $25 \mathrm{kV}$. A counting time of $200 \mathrm{~s}$ was used for $\mathrm{Al}, \mathrm{Cr}, \mathrm{Nb}, \mathrm{V}$ and $\mathrm{Zr}, 100 \mathrm{~s}$ were used for Fe, Si, Sn, and $\mathrm{W}$ and $15 \mathrm{~s}$ for Ti. Garnet was analysed with a beam current of $20 \mathrm{nA}$ and an accelerating voltage of $15 \mathrm{kV}$. The counting times per spot were $15 \mathrm{~s}$ for $\mathrm{Al}, \mathrm{Ca}, \mathrm{Fe}, \mathrm{Mg}$ and $\mathrm{Si}$ and $30 \mathrm{~s}$ for $\mathrm{Cr}, \mathrm{Mn}$ and $\mathrm{Ti}$. Detection limits and standard errors are given in the supplementary material (Table S2) together with the analytical data.

To visualise the datasets obtained from electron microprobe analyses and their variability, a principal component analysis (PCA) was performed with the centred log-ratio transformed chemical data for rutile and garnet, respectively. The log-ratio transformation is necessary to account for the compositional nature of the data (Aitchison, 1986). Values below the detection limit were replaced by 0.65 times the detection limit, as suggested by MartínFernández et al. (2003), to make sure that the dataset for log-ratio transformation does not contain any zeros.

Rutile growth temperature was assessed using the latest Zr-in-rutile thermometer introduced by Tomkins et al. (2007) in the $\alpha$-quartz field after the following equation:

$\mathrm{T}\left({ }^{\circ} \mathrm{C}\right)=((83.9+0.410 P) /(0.1428-R \ln (\mathrm{Zr}[\mathrm{ppm}])))-273$ 
$\mathrm{R}$ is the gas constant with $0.0083144 \mathrm{~kJ} \mathrm{~K}^{-1}$. A default pressure $\mathrm{P}$ of $10 \mathrm{kbar}$ was used, as proposed by Triebold et al. (2012) for detrital rutile with unknown growth pressure conditions. The dependency of $\mathrm{Cr}$ and $\mathrm{Nb}$ concentrations in rutile on host rock chemistry was used to deduce the proportions of metamafic and metafelsic rutiles with the following $\mathrm{Cr}-\mathrm{Nb}$ separation line after Triebold et al. (2012):

$\mathrm{x}=5(\mathrm{Nb}[\mathrm{ppm}]-500)-\mathrm{Cr}[\mathrm{ppm}]$

Here, rutiles from metamafic rocks yield negative values for $\mathrm{x}$, while for rutiles from metafelsic rocks $\mathrm{x}$ is positive.

The assignment of detrital garnet to certain source lithologies is difficult given the complex control of garnet composition by host rock chemical composition and pressure and temperature during formation (e.g. Krippner et al., 2014; Tolosana-Delgado et al., 2018). To account for the overlap of compositional fields of garnets from different host rock lithologies and the need for robust multivariate statistical methods for garnet classification, TolosanaDelgado et al. (2018) proposed a new discrimination scheme, which is applied in this study. It is hierarchical, based on linear discriminant analysis and gives a set of probabilities for a garnet grain of belonging to one of the five host rock categories: igneous rocks, ultramafic rocks or eclogite-, amphibolite- and granulite-facies metamorphic rocks.

\section{Results}

\subsection{Heavy mineral analysis}

The full data set obtained during optical heavy mineral analysis and Raman spectroscopy is available in the supplementary material to this article (Table S1). The proportions of heavy minerals with respect to the bulk of the respective grain size fractions used for separation are low. Heavy mineral yields vary between $0.01 \mathrm{wt} \%$ and $3.94 \mathrm{wt} \%$ of the respective grain size fraction with most yields below $1 \mathrm{wt} \%$ (Table S1). No systematic difference between the two formations is visible in the heavy mineral yield. The ratio between translucent and opaque grains is highly variable and no pattern is observable (Table S1). An overview of photomicrographs of the most common heavy minerals in the studied samples is given in Figure 3. The analysis of the heavy mineral assemblages reveals distinct differences between samples of the Enticho Sandstone and the Edaga Arbi Glacials. The heavy mineral suite of the Enticho Sandstone, especially the upper, marine, subunit, is dominated by the ultra-stable minerals zircon, rutile and tourmaline (Fig. 4). The lower glaciogenic subunit contains significant amounts of garnet and in some samples apatite and staurolite (Fig. 4). The highest garnet content in the Enticho Sandstone is found in sample Enti-4, which is taken from the basal tillite. Moreover, monazite is a common mineral in the Enticho Sandstone.

In the Edaga Arbi Glacials, the proportion of the ultra-stable heavy minerals is much lower. Instead, apatite and garnet make up the largest heavy mineral groups, but with strongly varying relations (Fig. 4). Garnet contents range from zero to $86 \%$ and apatite contents from 7 to $77.1 \%$ (Fig. 4, Table S1). Remarkable is the exceptionally high epidote content in two samples from the Edaga Arbi Glacials (Eda-6 with 45\% and Eda-12 with 50.6\%). Regarding the $\mathrm{TiO}_{2}$ polymorphs (rutile, anatase and brookite), differentiated by Raman spectroscopy, rutile constitutes more than $80 \%$ in most studied samples, (Table S1). However, some samples, especially in the Edaga Arbi Glacials, contain considerable amounts of anatase and brookite intergrowths.

For four samples, two from each formation, the heavy mineral assemblages in the grain size fractions $40-63 \mu \mathrm{m}$ and $125-250 \mu \mathrm{m}$ were analysed additionally to reveal the influence of the chosen grain size window (Fig. 5). Generally, the same heavy mineral assemblage can be 
observed within different grain size fractions of one sample, but with varying proportions of the respective minerals. It is evident that zircon preferentially occurs in the finest grain size fraction, whereas tourmaline and garnet are more abundant in the largest grain size fraction. An exception is sample Enti-4, where staurolite and monazite occur in the largest fraction, which are not present in the two finer fractions. Figure 5 also reveals differences in heavy mineral identification optically and using Raman spectroscopy; the $63-125 \mu \mathrm{m}$ fraction of these four samples was counted with both methods. The result is similar, however, tourmaline and minerals of the epidote group are generally overestimated during optical counting, whereas garnet is underestimated (Fig. 5).

The two studied formations can well be discriminated using heavy mineral indices (e.g. Morton and Hallsworth, 1994; Table 2). The dominance of the ultra-stable heavy minerals in the Enticho Sandstone is shown in the zircon-tourmaline-rutile (ZTR) index of 79.7 on average. In the Edaga Arbi Glacials ZTR is on average 13.4. On the other hand, the high proportions of garnet and apatite in the Edaga Arbi Glacials are reflected in a garnettourmaline index (GTi) of 88.3 and an apatite-tourmaline index (ATi) of 88.7. In the Enticho Sandstone these indices are on average 17.3 and 14.6, respectively. The rutile-zircon index (RZi) is higher in the Edaga Arbi Glacials with a mean of 43.0, while in the Enticho Sandstone RZi is 20.4 on average. The staurolite-tourmaline index (STi) is higher in the Enticho Sandstone (14.4) than in the Edaga Arbi Glacials (0.9; Table 2).

\subsection{Rutile chemistry}

The PCA biplot of the rutile chemical data gives a first overview of the variability within the data set. The colour code by formation reveals clustering of the samples from the Enticho Sandstone and the Edaga Arbi Glacials, respectively. Rutiles from the Enticho Sandstone are enriched in $\mathrm{Zr}, \mathrm{V}$ and $\mathrm{Nb}$, whereas rutiles from the Edaga Arbi Glacials contain more Al and Fe (Fig. 6). A group of rutiles from the Enticho Sandstone is enriched in Fe as well and is dominated by rutiles in sample Enti-6 (Fig. 6). When looking at the first and third principal component (Fig. 6b), a group of rutile grains in the Enticho Sandstone is striking that is significantly depleted in Al compared to all other grains. This group is not from one single sample but contains grains from all analysed Enticho Sandstone samples (Fig. 6).

According to the Zr-in-rutile thermometry after Tomkins et al. (2007), most analysed rutiles have grown under amphibolite-/eclogite-facies thermal conditions (ca. $500-750{ }^{\circ} \mathrm{C}$ for metapelitic rutiles following Zack et al., 2004), while both formations contain also granulitefacies rutiles $\left(>750{ }^{\circ} \mathrm{C}\right.$, following Zack et al., 2004; Fig. 7). The proportion of granulite-facies rutiles is higher in the Enticho Sandstone (mean: 17.7\%, range: 10.6-22.7\%) than in the Edaga Arbi Glacials (mean: 15.8\%, range: 7.0-33.3\%). According to the source rock lithological assessment using the $\mathrm{Cr}$ and $\mathrm{Nb}$ contents most of the rutile grains in both formations are probably from metafelsic host rocks (Fig. 7). The Edaga Arbi Glacials contain a higher proportion of rutile grains that might be derived from metamafic sources (mean: 39.8\%, range: $28.9-48.7 \%$ ) than the Enticho Sandstone (mean: $27.0 \%$, range: $16.7-34.0 \%$ ).

\subsection{Garnet chemistry}

Garnet chemical analyses yield similar compositions for garnets from the Enticho Sandstone and from the Edaga Arbi Glacials. In a PCA biplot no clear clustering is visible (Fig. S3). However, garnets in the Enticho Sandstone appear to be slightly more Mn-rich (spessartine), while garnets in the Edaga Arbi Glacials are more Fe-rich (almandine). According to the garnet classification scheme after Tolosana-Delgado et al. (2018) most garnets are derived from metamorphic rocks. Both formations contain also a significant amount of garnets 
classified as from felsic igneous rocks, which is higher in the Enticho Sandstone (11.5\%) than in the Edaga Arbi Glacials (5.9\%; Fig. 8). Only one garnet grain in a sample from the Enticho Sandstone is classified with the highest probability as from an ultramafic source. The metamorphic garnets are mostly classified as derived from amphibolite-facies and to a minor extent from granulite-facies metamorphic rocks (Fig. 8). Only a few metamorphic garnets are with high probabilities from eclogite-facies sources. The proportion of metamorphic garnets probably from granulite-facies rocks is higher in the Enticho Sandstone (average: $29 \%$, range 16.7-43.8\%) than in the Edaga Arbi Glacials (average: 16.9\%, range: 8.9-34.0\%; Fig. 8). Within the formations, inter-sample variations can be observed. In the Enticho Sandstone, samples Enti-4 and Enti-5 contain more high-grade metamorphic garnets than the other samples (Fig. 8a). In the Edaga Arbi Glacials, a tendency to high metamorphic grades can be observed for sample Eda-9 (Fig. 8b).

\section{Discussion}

\subsection{Enticho Sandstone (Ordovician-Silurian)}

The very high proportion of ultra-stable heavy minerals (ZTR; Fig. 4) and monazite, hence the very high mineralogical maturity, is untypical for glaciogenic sediments. In an ice-house climate chemical weathering is poor. An explanation for the high maturity can be the recycling of older sediments or sedimentary rocks that have undergone substantial diagenetic modification dissolving unstable minerals (e.g. Garzanti, 2017). Typical indicators for recycled sedimentary rocks, such as abraded quartz overgrowth or sedimentary lithoclasts, have not been identified during petrographic analyses. However, if the sediment incorporated and transported by the glaciers and meltwater of the Hirnantian glaciation was not significantly lithified, such indicators are less pronounced. As parent sediment for the Enticho Sandstone, the Cambrian-Ordovician quartzarenites that covered much of northern Gondwana (e.g. Garfunkel, 2002, Avigad et al., 2005) are a likely candidate. It is unlikely that these sediments have been buried to a depth in which substantial diagenetic dissolution of unstable minerals took place before they were taken up by the Hirnantian glaciers. However, the high maturity of the parent sediment may have been caused by strong chemical surface weathering due to warm and humid climate conditions combined with a low relief and low sedimentation rates in the aftermath of the Pan-African orogeny under a corrosive CambrianOrdovician atmosphere, as suggested by Avigad et al. (2005). The Enticho Sandstone may thus represent reworked Cambrian-Ordovician sediments leading to its strikingly high maturity. This assumption is also made for Hirnantian glaciogenic sandstones in Saudi Arabia (Hussain et al., 2004; Knox et al., 2007; Bassis et al., 2016a, b).

The glaciogenic basal part of the Enticho Sandstone, however, does also contain substantial amounts of less stable minerals, mainly garnet. This is particularly true for sample Enti-4, which was taken from the basal tillite (Fig. 4). High proportions of garnet have also been observed in Hirnantian sandstones in Israel (Weissbrod and Bogoch, 2007) and ascribed to proximal sources since glacio-fluvial channels cut deeply into the basement. In Libya, an increase in garnet content, together with an increase in $\mathrm{RZi}$ is observed at the base of the Tanezzuft Formation (Morton et al., 2011; Morton et al., 2012), which is equivalent to the shallow marine part of the Enticho Sandstone (Fig. 9b). This shift is ascribed to the final pulse of the Hirnantian glaciation, during which glaciers have cut deeply into the hinterland and brought new material, which was then reworked during transgression. In the Enticho Sandstone, there are numerous indications of several glacier advance-retreat cycles, such as large and intense deformation structures in the glaciogenic sediments and the occurrence of tunnel valleys filled with glaciogenic sediments and eroded into older glaciogenic sediments. The unstable heavy minerals in the basal glaciogenic sediments may thus have been derived 
from intensive erosion during the first glacier advance. The subsequent glacial advances probably did not erode these glaciogenic sediments down to the basement, so that fresh basement material was not admixed during the subsequent advances. In Saudi Arabia, Hirnantian sandstones are devoid of garnet (Bassis et al., 2016b), so glacial erosion of the basement was probably geographically variable. The absence of garnet in the shallow marine upper part of the Enticho Sandstone may be a consequence of selective removal during diagenesis. Corrosive pore fluids could penetrate the well-sorted and highly permeable marine sandstone better than the less permeable glaciogenic part of the formation. Corroded garnet surfaces that could be observed during optical investigation of the heavy mineral concentrates (Fig. 3, lower left image) further indicate such dissolution effects. The interpretation of the garnet content as a provenance signal should, therefore, be taken with caution.

Despite the above-mentioned differences in garnet content, the heavy mineral assemblages in Ethiopia, Saudi Arabia and Libya are largely similar in the Ordovician-Silurian succession, as illustrated in the heavy mineral index cross plots (Fig. 9). This supports the hypothesis of continent-scale homogenisation of the sediment in the early Palaeozoic. RZi is notably higher in some Libyan samples, likely implying a higher influence of metamorphic sources (Fig. 9). In the Enticho Sandstone, the ratio of metamorphic and magmatic sources, as mirrored in RZi, is rather constant with little variation between the samples (Fig. 9). Rutile and garnet chemical analyses point to mainly amphibolite-facies metamorphic source rocks, while both provide evidence for a certain contribution of granulite-facies sources as well (Fig. 7, Fig. 8). For rutile, the ratio of granulite-facies to amphibolite-facies grains is quite constant from sample to sample in the Enticho Sandstone, while garnet displays significant inter-sample variations (Fig. 10). In samples Enti-4 and Enti-5 the proportion of garnets probably from granulitefacies sources is much higher than in the other samples (Fig. 10). These samples are those with the highest garnet content, so that the ratio may be more reliable than for the other samples. Post-depositional dissolution may have affected different garnet-types differently. Additionally, it must be noted that the ratios are based on probabilities that grains grew under the respective metamorphic conditions and not on a distinct classification (Tolosana-Delgado et al., 2018). If the inter-sample differences are not an artefact, they indicate that in the Enticho Sandstone there have been geographical differences in the contribution of different source areas and that garnet and rutile are, at least partly, from different sources.

Rutile, as a chemically and physically very stable heavy mineral, can have been sourced from the reworked sediment incorporated in the Enticho Sandstone. The original provenance of this material is unclear, but following the Gondwana super-fan hypothesis, it may have originated in the central part of the East African Orogen (Mozambique Belt). Amphibolite to granulitefacies metamorphic rocks are abundant there (e.g. Stern et al., 2012; Fritz et al., 2013) and may have supplied the rutile. The group of Fe-rich rutiles in sample Enti-6 (Fig. 6) shows that differences in provenance exist within the Enticho Sandstone. Since this sample is taken from the shallow marine upper part of the formation, it may indicate that locally different material is brought to the basin during the transgression.

The garnet is probably derived from fresh basement material, which was eroded by the glaciers of the Hirnantian glaciation. The local basement in northern Ethiopia comprises mainly greenschist-facies metamorphic rocks (Beyth, 1972b; Kazmin et al., 1978; Tefera et al., 1996), but in the vicinity of intrusions, higher temperatures may have led to amphibolitefacies metamorphism. Reconstructions of the Hirnantian ice sheet assume the ice spreading centre to be in north-west Africa (Ghienne et al., 2007; Le Heron and Craig, 2008; Torsvik and Cocks, 2013), making a western provenance likely. Amphibolite- to granulite-facies rocks 
are present in the Saharan Metacraton (e.g. Abdelsalam et al., 2002) and may have supplied the garnet. Garnet chemistry further reveals a certain proportion of garnets that originate with high probability from felsic igneous rocks (Fig. 8). Such rocks are, however, abundant in all parts of the East African Orogen and elsewhere in northern and central Gondwana, making it difficult to deduce any source area.

Summarizing, the heavy mineral assemblage of the Enticho Sandstone is probably a consequence of 1) reworking of mature sand by glaciers of the Hirnantian glaciation, 2) admixing garnet-rich material eroded by the glaciers from the basement, and 3) postdepositional modification by dissolution of chemically unstable minerals, especially in the well-sorted and highly permeable marine part of the formation. The reworked mature sediments may have belonged to the postulated super-fans that transported large amounts of material towards the Gondwana margins during the early Palaeozoic (Squire et al., 2006; Meinhold et al., 2013; Stephan et al., 2019), a hypothesis that is also underlined by detrital zircon age spectra in the Enticho Sandstone (Lewin et al., 2020). The variably admixed fresh basement material that delivered the garnet may origin from sources in the Saharan Metacraton. A northwesterly source area for the Enticho Sandstone is supported by palaeocurrent directions derived from the dip direction of foreset beds within cross-bedded sandstone (Bussert and Dawit, 2009).

\subsection{Edaga Arbi Glacials (Carboniferous-Permian)}

In the Edaga Arbi Glacials, apatite and garnet, and in two samples epidote, are present with very high proportions (Fig. 4). This means that 1) the formation cannot be (solely) the product of recycling of the Enticho Sandstone and 2) very little chemical alteration of the sediment must have taken place. Besides the generally low influence of chemical weathering in glacial environments, it may indicate short transport of the material, with little time for temporal storage and weathering. Furthermore, the potential of post-depositional intrastratal dissolution was lower in the Edaga Arbi Glacials, because the sandstone is poorly sorted with significant proportions of clay. The clay may have filled the pores avoiding the penetration of corrosive fluids (see also petrographic description in Lewin et al., 2018).

An increase in garnet content in the Upper Palaeozoic is also observed in Libya at the base of the Carboniferous Mrar Formation (Morton et al., 2011) and in Saudi Arabia in the Carboniferous-Permian glaciofluvial Juwayl Formation (Bassis et al., 2016b) and interpreted as a change in provenance. The comparison of heavy mineral indices of the Upper Palaeozoic sandstones in these regions to the Edaga Arbi Glacials (Fig. 9), however, reveals substantial differences. In all plots presented in Figure 9, the Edaga Arbi Glacials differ significantly from all other formations. The heavy mineral assemblage is thus not regionally correlative and probably the result of local provenance and sedimentary conditions. Striking is particularly the high abundance of apatite and the absence of staurolite in the Edaga Arbi Glacials as compared to stratigraphically equivalent formations in Saudi Arabia and Libya (Fig. 9). Apatite is abundant in many magmatic and metamorphic rocks and widespread in the northern Ethiopian basement. This is supported by geochemical analyses of some samples from the local basement that revealed relative enrichment in phosphorus (Lewin et al., 2018, Fig. 10a). The high epidote content in two samples, Eda-6 and Eda-12 (Fig. 4), may be due to a very proximal provenance of the material and could be derived from the greenschist-facies metavolcanics of the Tsaliet Group (Beyth, 1972b; Miller et al., 2009).

Garnet and rutile chemistry indicate mainly amphibolite- but also granulite-facies metamorphic rocks as sources, though to a smaller proportion as in the Enticho Sandstone 
(Fig. 7, Fig. 8, Fig. 10). The ratio of granulite- and amphibolite-facies garnet and rutile is similar so that both minerals could be derived from the same source rocks (Fig. 10). The separation of rutile in both formations according to its chemical composition, as revealed in the PCA biplot (Fig. 6) indicates that rutile in the Edaga Arbi Glacials is, at least partly, derived from a different source area than rutile in the Enticho Sandstone. This is also indicated by the different proportions of rutile assigned to metamafic and metafelsic host rocks by their $\mathrm{Cr}-\mathrm{Nb}$ contents with a higher proportion of metamafic rutiles in the Edaga Arbi Glacials (Fig. 7). The greenschist-facies metamorphism of the local basement in northern Ethiopia, as discussed above, questions a very local provenance for the rutile and garnet in the Edaga Arbi Glacials. The transport direction is inferred from south to north based on the orientation and geometry of palaeolandforms, such as roche moutonnées (Bussert, 2010). The amphibolite- and granulite-facies garnets and rutiles may thus be derived from the high-grade metamorphic rocks in the Southern and Western Ethiopian Shields (Yibas et al., 2002; Woldemichael et al., 2010; Stern et al., 2012). Striking is the exceptionally high proportion of granulite-facies rutiles and garnets in sample Eda-9 (Fig. 10). Raman spectroscopy of this sample revealed that it contains also significant amounts of anatase and brookite, which may have led to erroneous results of Zr-in-rutile thermometry. However, for Raman spectroscopy, random grain mounts were analysed, and we assume that during picking of rutile grains for microprobe analysis rutile is selected intuitively. An analysis of the picked rutile trace element composition after Triebold et al. (2010) resulted in rutile being the dominant $\mathrm{TiO}_{2}$ polymorph in the mounts for single-grain analysis $(99.4 \%$ of all grains, in sample Eda- 9 $98 \%$ ). Furthermore, garnet chemistry shows a similar proportion of granulite-facies grains in sample Eda-9, which is much higher than in the other samples (Fig. 8, Fig. 10). This leads to the assumption of geographic (and maybe also stratigraphic) differences in provenance within the Edaga Arbi Glacials. Such differences are also indicated by the generally less uniform and systematic heavy mineral assemblage in the Edaga Arbi Glacials compared to that of the Enticho Sandstone (Fig. 4) and by the variations in RZi (Fig. 9).

A rather proximal provenance for the Edaga Arbi Glacials is in accordance with earlier findings from petrographic and geochemical analyses and detrital zircon geochronology (Lewin et al., 2018; Lewin et al., 2020) and supports the assumption of a complex pattern of local ice sheets during the Late Palaeozoic Ice Age (e.g. Eyles 1993; Fielding et al. 2008). In north-east Africa, complex local geomorphology evolved during 'Hercynian' tectonism (AlHusseini, 1992; Sharland et al., 2004), leading to mountain glaciers during the Late Palaeozoic Ice Age (Konert et al., 2001; Bussert and Schrank, 2007; Le Heron et al., 2009). Alternatively, thermal up-doming prior to the formation of the Zagros rift zone, which later formed the Neo-Tethys ocean, could have caused basement uplift (Sharland et al., 2001). The glaciers then could effectively erode material from the uplifted areas and transport it to nearby depocentres, leading to the immature heavy mineral assemblage found in the Edaga Arbi Glacials.

The findings show that no major recycling of the Enticho Sandstone by the Edaga Arbi Glacials took place. This is probably because the deposition of the Enticho Sandstone was limited to northern Ethiopia (Kazmin, 1972; Tefera et al., 1996), while the inferred source area of the Edaga Arbi Glacials is to the south.

\section{Conclusions}

A summary of the main findings of this study is given in Figure 11. The study of heavy minerals in the Ordovician-Silurian Enticho Sandstone and the Carboniferous-Permian Edaga Arbi Glacials revealed significant differences in the heavy mineral assemblages. The 
Enticho Sandstone is characterised by a highly mature heavy mineral assemblage, which is uncommon for glaciogenic sediments. We, therefore, conclude that it is composed of recycled material of older sediments. Additionally, various proportions of garnet, especially in the tillite, indicate an admixture of fresh basement material through glacial erosion. Heavy mineral assemblage and rutile and garnet chemical analyses point to magmatic and metamorphic source rocks with metamorphic temperatures of mainly amphibolite-, but also granulite-facies grade. Garnet and rutile are not necessarily derived from the same metamorphic host rocks. The recycled/reworked sediments incorporated in the Enticho Sandstone may have been part of the Gondwana super-fan system that transported large amounts of sediment from the inner part of the continent to the margins. The original provenance of the material remains unclear. The fresh basement material delivering the garnet could originate from the Saharan Metacraton.

The heavy mineral assemblage of the Edaga Arbi Glacials is dominated by less stable minerals, mainly garnet and apatite. Therefore, very little chemical weathering of the sediment must have taken place. We assume a more proximal provenance for the Edaga Arbi Glacials. The source area is characterised by magmatic and metamorphic rocks as well. Rutile and garnet chemistry indicate mainly amphibolite metamorphic temperatures, while also granulite-facies host rocks were inferred. Rutile in the Edaga Arbi Glacials and the Enticho Sandstone are probably from different host rocks, as inferred from differences in trace element compositions. The local basement in northern Ethiopia experienced only greenschistfacies metamorphism, but higher metamorphic grades were reached in the southern ArabianNubian Shield (Western and Southern Ethiopian Shields). This agrees with an assumed transport direction of the Edaga Arbi Glacials from south to north. Since the deposition of the Enticho Sandstone was probably limited to northern Ethiopia, no recycling by the Edaga Arbi Glacials took place.

These findings confirm previous assumptions of reworked mature sediment as the major constituent of the Enticho Sandstone and a proximal provenance for the Edaga Arbi Glacials. They also support previous models for the two glaciations with a large ice sheet covering northern Gondwana in the Late Ordovician and a complex pattern of local glaciers in the Carboniferous-Permian.

\section{Acknowledgements}

This work was supported by the German Research Foundation (DFG grants HI 643/13-1, ME 3882/4-1). We are grateful to Andreas Kronz for providing access to the electron microprobe, and to Judit Dunklne-Nagy and Reimund Rosmann for assistance in the preparation of the grain mounts. Careful and constructive reviews by Andrew C. Morton and an anonymous reviewer are greatly appreciated.

\section{Data availability}

The heavy mineral counts and the analytical data from rutile and garnet chemical analyses, as well as three supplementary figures can be found along with the online version of this article.

\section{Competing interests}

The authors declare that they have no conflict of interest. 


\section{References}

Abdelsalam, M. G., Liégeois, J.-P., and Stern, R. J.: The Saharan Metacraton, J. Afr. Earth Sci., 34, 119-136, https://doi.org/10.1016/S0899-5362(02)00013-1, 2002.

Aitchison, J.: The statistical analysis of compositional data, Chapman and Hall, London, UK, New York, USA, 1986.

Al-Husseini, M. I.: Upper Palaeozoic tectono-sedimentary evolution of the Arabian and adjoining plates, J. Geol. Soc. London, 149, 419-129, https://doi.org/10.1144/gsjgs.149.3.0419, 1992.

Alene, M., Jenkin, G. R. T., Leng, M. J., and Darbyshire, D. P. F.: The Tambien Group, Ethiopia: An early Cryogenian (ca. 800-735Ma) Neoproterozoic sequence in the Arabian-Nubian Shield, Precambrian Res., 147, 79-99, https://doi.org/10.1016/j.precamres.2006.02.002, 2006.

Arkin, Y., Beyth, M., Dow, D. B., Levitte, D., Temesgen, H., and Tsegaye, H.: Geological Map of Mekele Area, sheet ND 37-11, Geological Survey of Ethiopia, Addis Ababa, 1971.

Avigad, D., Sandler, A., Kolodner, K., Stern, R., McWilliams, M., Miller, N., and Beyth, M.: Mass-production of Cambro-Ordovician quartz-rich sandstone as a consequence of chemical weathering of Pan-African terranes: Environmental implications, Earth Planet. Sci. Lett., 240, 818-826, https://doi.org/10.1016/j.epsl.2005.09.021, 2005.

Avigad, D., Stern, R. J., Beyth, M., Miller, N., and McWilliams, M. O.: Detrital zircon U-Pb geochronology of Cryogenian diamictites and Lower Paleozoic sandstone in Ethiopia (Tigrai): Age constraints on Neoproterozoic glaciation and crustal evolution of the southern Arabian-Nubian Shield, Precambrian Res., 154, 88-106, https://doi.org/10.1016/j.precamres.2006.12.004, 2007.

Avigad, D., Morag, N., Abbo, A., and Gerdes, A.: Detrital rutile U-Pb perspective on the origin of the great Cambro-Ordovician sandstone of North Gondwana and its linkage to orogeny, Gondwana Res., 51, 17-29, https://doi.org/10.1016/j.gr.2017.07.001, 2017.

Bassis, A., Hinderer, M., and Meinhold, G.: Petrography and geochemistry of Palaeozoic quartz-rich sandstones from Saudi Arabia: implications for provenance and chemostratigraphy. Arab. J. Geosci., 9, https://doi.org/10.1007/s12517-016-2412-z, 2016a.

Bassis, A., Hinderer, M., and Meinhold, G.: New insights into the provenance of Saudi Arabian Palaeozoic sandstones from heavy mineral analysis and single-grain geochemistry, Sediment. Geol., 333, 100-114, https://doi.org/10.1016/j.sedgeo.2015.12.009, 2016b.

Beyth, M.: Paleozoic-Mesozoic sedimentary basin of the Mekele Outlier, Northern Ethiopia, Am. Assoc. Pet. Geol. Bull., 56, 2426-2439, 1972a.

Beyth, M.: To the geology of central-western Tigre, PhD, Mathematisch-Naturwissenschaftliche Fakultät, Rheinische Friedrich-Wilhelms-Universität Bonn, Bonn, 159 pp., 1972 b.

Brocke, R., Bussert, R., and Dawit, E. L.: First discovery of Early Palaeozoic post-glacial (post-Hirnantian/latest Ordovician-early Silurian) mudstones and cryptospores in northern Ethiopia, Annual Meeting of DGGV and DMG, 4-7 October 2015, Berlin, 2015, 100, 2015.

Bussert, R., and Schrank, E.: Palynological evidence for a latest Carboniferous-Early Permian glaciation in Northern Ethiopia, J. Afr. Earth Sci., 49, 201-210, https://doi.org/10.1016/j.jafrearsci.2007.09.003, 2007.

Bussert, R., and Dawit, E. L.: Unexpected diversity: New results on the stratigraphy and sedimentology of Palaeozoic and Mesozoic siliciclastic sediments in Northern Ethiopia, Zentralblatt für Geologie und Paläontologie, Teil I, 181-198, 2009.

Bussert, R.: Exhumed erosional landforms of the Late Palaeozoic glaciation in northern Ethiopia: Indicators of ice-flow direction, palaeolandscape and regional ice dynamics, Gondwana Res., 18, 356-369, https://doi.org/10.1016/j.gr.2009.10.009, 2010.

Bussert, R.: Depositional environments during the Late Palaeozoic ice age (LPIA) in northern Ethiopia, NE Africa, J. Afr. Earth Sci., 99, 386-407, https://doi.org/10.1016/j.jafrearsci.2014.04.005, 2014.

Dawit, E. L.: Adigrat Sandstone in Northern and Central Ethiopia: Stratigraphy, Facies, Depositional Environments and Palynology, PhD, Fakultät VI - Planen Bauen Umwelt, Berlin Technical University, Berlin, 2010.

Dawit, E. L.: Permian and Triassic microfloral assemblages from the Blue Nile Basin, central Ethiopia, J. Afr. Earth Sci., 99, 408-426, https://doi.org/10.1016/j.jafrearsci.2014.04.011, 2014.

Dow, D. B., Beyth, M., and Hailu, T.: Palaeozoic glacial rocks recently discovered in northern Ethiopia, Geol. Mag., 108, 53-60, 1971.

Eyles, N.: Earth's glacial record and its tectonic setting, Earth Sci. Rev., 35, 1-248, https://doi.org/10.1016/00128252(93)90002-O, 1993.

Fielding, C.R., Frank, T.D., and Isbell, J.L.: The late Paleozoic ice age - a review of current understanding and synthesis of global climate patterns. In:

Fielding, C.R., Frank, T.D. \& Isbell, J.L. (eds): Resolving the Late Paleozoic Ice Age in Time and Space. Geological Sciety of America, Special Papers, 441, 343-354, https://doi.org/10.1130/2008.2441(24), 2008. 
Fritz, H., Abdelsalam, M., Ali, K. A., Bingen, B., Collins, A. S., Fowler, A. R., Ghebreab, W., Hauzenberger, C. A., Johnson, P. R., Kusky, T. M., Macey, P., Muhongo, S., Stern, R. J., and Viola, G.: Orogen styles in the East African Orogen: A review of the Neoproterozoic to Cambrian tectonic evolution, J. Afr. Earth Sci., 86, 65-106, https://doi.org/10.1016/j.jafrearsci.2013.06.004, 2013.

Garfunkel, Z.: Early Paleozoic sediments of NE Africa and Arabia: Products of continental-scale erosion, sediment transport and deposition, Israel J. Earth Sci., 51, 135-156, 2002.

Garland, C.R., Akililu, A., Assefa, A., Amenti, A., Beyth, M., Dow, D.B., Temesgen, H., and Tsegaye, H.: Geological map of Adigrat, sheet ND37-7, Geological Survey of Ethiopia, Addis Ababa, 1978.

Garzanti, E.: The maturity myth in sedimentology and provenance analysis, J. Sediment. Res., 87, 353-365, https://doi.org/10.2110/jsr.2017.17, 2017.

Ghienne, J.-F., Le Heron, D. P., Moreau, J., Denis, M., and Deynoux, M.: The Late Ordovician glacial sedimentary system of the North Gondwana platform. In: Hambrey, M. J., Christoffersen, P., Glasser, N. F., and Hubbard, B. (eds.): Glacial sedimentary processes and products, International Association of Sedimentologists Special Publication, Malden, USA, Oxford, UK, Victoria, Australia, 295-319, 2007.

Hussain, M., Babalola, L. O., and Hariri, M. M.: Heavy minerals in the Wajid Sandstone from Abha-Khamis Mushayt area, southwestern Saudi Arabia: implications on provenance and regional tectonic setting, GeoArabia, 9, 77-102, 2004.

Johnson, P. R., Andresen, A., Collins, A. S., Fowler, A. R., Fritz, H., Ghebreab, W., Kusky, T., and Stern, R. J.: Late Cryogenian-Ediacaran history of the Arabian-Nubian Shield: A review of depositional, plutonic, structural, and tectonic events in the closing stages of the northern East African Orogen, J. Afr. Earth Sci., 61, 167-232, https://doi.org/10.1016/j.jafrearsci.2011.07.003, 2011.

Johnson, P. R.: An Expanding Arabian-Nubian Shield Geochronologic and Isotopic Dataset: Defining Limits and Confirming the Tectonic Setting of a Neoproterozoic Accretionary Orogen, The Open Geology Journal, $8,3-33,2014$

Kazmin, V.: Geological Map of Ethiopia, Geological Survey of Ethiopia, Addis Abeba, 1972.

Kazmin, V., Shifferaw, A., and Balcha, T.: The Ethiopian basement: Stratigraphy and Possible Manner of Evolution, Geol. Rundschau, 67, 531-546, https://doi.org/10.1007/BF01802803, 1978.

Keller, M., Hinderer, M., Al-Ajmi, H., Rausch, R.: Palaeozoic glacial depositional environments of SW Saudi Arabia: process and product, Geol. Soc. London, Special Publications, 354, 129-152, https://doi.org/10.1144/SP354.8, 2011.

Knox, R. W. O. B., Franks, S. G., and Cocker, J. D.: Stratigraphic evolution of heavy-mineral provenance signatures in the sandstones of the Wajid group (Cambrian to Permian), southwestern Saudi Arabia, GeoArabia, 12, 65-96, 2007.

Konert, G., Afifi, A. M., Al-Hajri, S. A., and Droste, H. J.: Paleozoic stratigraphy and hydrocarbon habitat of the Arabian Plate, GeoArabia, 6, 407-442, 2001.

Krippner, A., Meinhold, G., Morton, A. C., and von Eynatten, H.: Evaluation of garnet discrimination diagrams using geochemical data of garnets derived from various host rocks, Sediment. Geol., 306, 36-52, https://doi.org/10.1016/j.sedgeo.2014.03.004, 2014.

Le Heron, D. P., and Craig, J.: First-order reconstructions of a Late Ordovician Saharan ice sheet, J. Geol. Soc. London, 165, 19-29, https://doi.org/10.1144/0016-76492007-002, 2008.

Le Heron, D. P., Craig, J., and Etienne, J. L.: Ancient glaciations and hydrocarbon accumulations in North Africa and the Middle East, Earth-Science Reviews, 93, 47-76, https://doi.org/10.1016/j.earscirev.2009.02.001, 2009.

Le Heron, D.P., Tofaif, S., and Melvin, J.: The Early Palaeozoic glacial

deposits of Gondwana: overview, chronology and controversies. In: Menzies, J. and van der Meer, J.J.M. (eds): Past Glacial Environments, 2nd edn. Elsevier, Amsterdam, 47-73, 2018.

Lewin, A., Meinhold, G., Hinderer, M., Dawit, E. L., and Bussert, R.: Provenance of sandstones in Ethiopia during Late Ordovician and Carboniferous-Permian Gondwana glaciations: Petrography and geochemistry of the Enticho Sandstone and the Edaga Arbi Glacials, Sedimentary Geology, 375, 188-202, https://doi.org/10.1016/j.sedgeo.2017.10.006, 2018.

Lewin, A., Meinhold, G., Hinderer, M., Dawit, E. L., Bussert, R., and Berndt, J.: Provenance of OrdovicianSilurian and Carboniferous-Permian glaciogenic successions in Ethiopia revealed by detrital zircon $\mathrm{U}-\mathrm{Pb}$ geochronology, J. Geol. Soc. London, 177, 141-152, https://doi.org/10.1144/jgs2019-027, 2020.

Lünsdorf, K., Kalies, J., Ahlers, P., Dunkl, I., and von Eynatten, H.: Semi-Automated Heavy-Mineral Analysis by Raman Spectroscopy, Minerals, 9, https://doi.org/10.3390/min9070385, 2019.

Mange, M., and Morton, A. C.: Geochemistry of heavy minerals, in: Heavy minerals in use, edited by: Mange, M., and Wright, D. T., Developments in Sedimentology, Elsevier, Amsterdam, 345-391, 2007.

Martín-Fernández, J. A., Barceló-Vidal, C., and Pawlowsky-Glahn, V.: Dealing with zeros and missing values in compositional data sets using nonparametric imputation, Math. Geol., 35, 253-278, https://doi.org/10.1023/A:1023866030544, 2003. 
Meinhold, G.: Rutile and its applications in earth sciences, Earth-Science Reviews, 102, 1-28, https://doi.org/10.1016/j.earscirev.2010.06.001, 2010.

Meinhold, G., Morton, A. C., and Avigad, D.: New insights into peri-Gondwana paleogeography and the Gondwana super-fan system from detrital zircon U-Pb ages, Gondwana Res., 23, 661-665, https://doi.org/10.1016/j.gr.2012.05.003, 2013.

Miller, N. R., Stern, R. J., Avigad, D., Beyth, M., and Schilman, B.: Cryogenian slate-carbonate sequences of the Tambien Group, Northern Ethiopia (I): Pre-“Sturtian" chemostratigraphy and regional correlations, Precambrian Res., 170, 129-156, https://doi.org/10.1016/j.precamres.2008.12.004, 2009.

Morag, N., Avigad, D., Gerdes, A., Belousova, E., and Harlavan, Y.: Detrital zircon Hf isotopic composition indicates long-distance transport of North Gondwana Cambrian-Ordovician sandstones. Geology 39, 955 958, https://doi.org/10.1130/G32184.1, 2011.

Morton, A. C.: Influences of provenance and diagenesis on detrital garnet suites in the Palaeocene Forties Sandstone, central North Sea, J. Sediment. Petrol., 57, 1027-1032, 1987.

Morton, A. C., and Hallsworth, C.: Identifying the provenance-specific features of detrital heavy mineral assemblages in sandstones, Sediment. Geol., 90, 241-256, https://doi.org/10.1016/0037-0738(94)90041-8, 1994.

Morton, A. C., Meinhold, G., Howard, J. P., Phillips, R. J., Strogen, D., Abutarruma, Y., Elgadry, M., Thusu, B., and Whitham, A. G.: A heavy mineral study of sandstones from the eastern Murzuq Basin, Libya: Constraints on provenance and stratigraphic correlation, J. Afr. Earth Sci., 61, 308-330, https://doi.org/10.1016/j.jafrearsci.2011.08.005, 2011.

Morton, A., Whitham, A., Howard, J., Fanning, M., Abutarruma, Y., El Dieb, M., Elkatarry, F., Hamhoom, A., Lüning, S., Phillips, R., Thusu, B.: Using heavy minerals to test the stratigraphic framework of Al Kufrah Basin. In: Salem, M.J. \& Abadi, A.M. (eds): Fourth Symposium on the Sedimentary Basins of Libya. The Geology of Southern Libya. Vol. 3. Earth Science Society of Libya, Tripoli, 33-76, 2012.

Saxena, G. N., and Assefa, G.: New evidence on the age of the glacial rocks of northern Ethiopia, Geol. Mag., 120, 549-554, 1983.

Sharland, P. R., Archer, R., Casey, D. M., Davies, R. B., Hall, S. H., Heward, A. P., Horbury, A. D., and Simmons, M. D.: Arabian Plate Sequence Stratigraphy, GeoArabia Special Publication, Gulf PetroLink, Bahrain, 2001.

Sharland, P. R., Casey, D. M., Davies, R. B., Simmons, M. D., and Sutcliffe, O. E.: Arabian Plate Sequence Stratigraphy - revisions to SP2, GeoArabia, 9, 199-214, 2004.

Squire, R. J., Campbell, I. H., Allen, C. M., and Wilson, C. J. L.: Did the Transgondwanan Supermountain trigger the explosive radiation of animals on Earth?, Earth Planet. Sci. Lett., 250, 116-133, https://doi.org/10.1016/j.epsl.2006.07.032, 2006.

Stephan, T., Kroner, U., and Romer, R. L.: The pre-orogenic detrital zircon record of the Peri-Gondwanan crust, Geol. Mag., 156, 281-307, https://doi.org/10.1017/s0016756818000031, 2019.

Stern, R. J., Ali, K. A., Abdelsalam, M. G., Wilde, S. A., and Zhou, Q.: U-Pb zircon geochronology of the eastern part of the Southern Ethiopian Shield, Precambrian Res., 206-207, 159-167, https://doi.org/10.1016/j.precamres.2012.02.008, 2012.

Stutenbecker, L., Berger, A., and Schlunegger, F.: The potential of detrital garnet as a provenance proxy in the Central Swiss Alps, Sediment. Geol., 351, 11-20, https://doi.org/10.1016/j.sedgeo.2017.02.002, 2017.

Tefera, M., Chernet, T., and Haro, W.: Explanation of the Geological Map of Ethiopia. Ministry of Mines and Energy Bulletin 3, Addis Ababa, Ethiopia, 1996.

Tolosana-Delgado, R., von Eynatten, H., Krippner, A., and Meinhold, G.: A multivariate discrimination scheme of detrital garnet chemistry for use in sedimentary provenance analysis, Sediment. Geol., 375, 14-26, https://doi.org/10.1016/j.sedgeo.2017.11.003, 2018.

Tomkins, H. S., Powell, R., and Ellis, D. J.: The pressure dependence of the zirconium-in-rutile thermometer, J. Metamorph. Geol., 25, 703-713, https://doi.org/10.1111/j.1525-1314.2007.00724.x, 2007.

Torsvik, T. H., and Cocks, L. R. M.: Gondwana from top to base in space and time, Gondwana Res., 24, 9991030, https://doi.org/10.1016/j.gr.2013.06.012, 2013.

Triebold, S., von Eynatten, H., Luvizotto, G. L., and Zack, T.: Deducing source rock lithology from detrital rutile geochemistry: An example from the Erzgebirge, Germany, Chem. Geol., 244, 421-436, https://doi.org/10.1016/j.chemgeo.2007.06.033, 2007.

Triebold, S., Luvizotto, G. L., Tolosana-Delgado, R., Zack, T., and von Eynatten, H.: Discrimination of TiO2 polymorphs in sedimentary and metamorphic rocks, Contrib. Mineral. Petr., 161, 581-596, https://doi.org/10.1007/s00410-010-0551-x, 2010.

Triebold, S., von Eynatten, H., and Zack, T.: A recipe for the use of rutile in sedimentary provenance analysis, Sediment. Geol., 282, 268-275, https://doi.org/10.1016/j.sedgeo.2012.09.008, 2012.

Tsige, L., and Hailu, F.: Geological Map of the Bure Area, sheet NC 37/5, Geological Survey of Ethiopia, Addis Ababa, 2007. 
von Eynatten, H., and Dunkl, I.: Assessing the sediment factory: The role of single grain analysis, Earth-Science Reviews, 115, 97-120, https://doi.org/10.1016/j.earscirev.2012.08.001, 2012.

Weissbrod, T., and Bogoch, R.: Distribution pattern and provenance implications of the heavy minerals in Neoproterozoic to Mesozoic siliciclastic successions in the Arabo-Nubian Shield and its northern periphery: a review. In: Mange, M. A., and Wright, D. T. (eds.): Heavy minerals in use, Developments in Sedimentology, 58, Elsevier, Amsterdam, Netherlands, 647-676, 2007.

Woldemichael, B. W., Kimura, J.-I., Dunkley, D. J., Tani, K., and Ohira, H.: SHRIMP U-Pb zircon geochronology and $\mathrm{Sr}-\mathrm{Nd}$ isotopic systematic of the Neoproterozoic Ghimbi-Nedjo mafic to intermediate intrusions of Western Ethiopia: a record of passive margin magmatism at $855 \mathrm{Ma}$, Int. J. Earth. Sci., 99, 1773-1790, https://doi.org/10.1007/s00531-009-0481-x, 2010.

Yibas, B., Reimold, W. U., Armstrong, R., Koeberl, C., Anhaeusser, C. R., and Phillips, D.: The tectonostratigraphy, granitoid geochronology and geological evolution of the Precambrian of southern Ethiopia, J. Afr. Earth Sci., 34, 57-84, 2002.

Zack, T., von Eynatten, H., and Kronz, A.: Rutile geochemistry and its potential use in quantitative provenance studies, Sediment. Geol., 171, 37-58, https://doi.org/10.1016/j.sedgeo.2004.05.009, 2004.

\section{Tables}

Table 1. Sample information. Locations are given in geographical coordinates (WGS84). The stratigraphic assignment to one of the two studied formations is based on biostratigraphic evidence (B), lithofacies characteristics (LF) in the outcrop or geochemical analyses (C). Detailed information on the petrography and geochemistry of each sample is given in Lewin et al. (2018).

Table 2. Heavy mineral indices (Morton and Hallsworth, 1994): ZTR = zircon + rutile + tourmaline; $\mathrm{RZi}=100 \times$ rutile $/($ rutile + zircon); $\mathrm{GZi}=100 \times$ garnet $/($ garnet + zircon); ATi $=100 \times$ apatite $/($ apatite + tourmaline $) ; \mathrm{STi}=100 \times$ staurolite $/$ (staurolite + tourmaline $)$.

\section{Figures}

Figure 1. Map of Gondwana showing the overall geological setting (modified after Torsvik and Cocks 2013; Avigad et al. 2017).

Figure 2. Maps of the study areas showing the sampling locations (after Lewin et al. 2018). (a) Northern Ethiopia (modified after Arkin et al. 1971, Garland 1978, Bussert 2014). (b) Blue Nile region (modified after Tsige and Hailu 2007, Dawit 2014). The term "Fincha Sandstone" is taken from Dawit (2014).

Figure 3. Photomicrographs of the most common heavy minerals in the studied samples. The bars represent $50 \mu \mathrm{m}$, respectively.

Figure 4. Heavy mineral assemblages in the 63-125 $\mu \mathrm{m}$ grain-size fractions of the studied samples. For samples marked with an asterisk $(*)$ the heavy minerals were identified using Raman spectroscopy, for the other samples with a polarising microscope. The samples are arranged according to their stratigraphic order as inferred during field work.

Figure 5. Comparison of the heavy mineral assemblages in the grain-size fractions $40-63 \mu \mathrm{m}$, 63-125 $\mu \mathrm{m}$ and $125-250 \mu \mathrm{m}$ for four samples. Note that the $63-125 \mu \mathrm{m}$ fraction was studied by both optical microscopy and Raman spectroscopy (*).

Figure 6. PCA biplot based on the centred log-ratio (clr) transformed concentrations of the measured trace elements in rutile from Enticho Sandstone and Edaga Arbi Glacials. (a) First 
and second principal component. (b) First and third principal component. (c) First and third principal component with colour-code by sample.

Figure 7. Left: histograms of the calculated formation temperatures from $\mathrm{Zr}$-in-rutile thermometry after Tomkins et al. (2007). Approximate temperature boundaries of metamorphic facies for metapelitic rutile following Zack et al. (2004). Right: $\mathrm{Cr}-\mathrm{Nb}$ crossplot and pie charts for classification of rutiles derived from metamafic and metafelsic source rocks after Triebold et al. (2012).

Figure 8. Garnet classification after Tolosana-Delgado et al. (2018) using the prior "global". For the pie charts, garnets were assigned to one class if the highest probability was calculated for the respective class, even if it was $<50 \%$. Ternary diagrams further classify the metamorphic garnets.

Figure 9. Cross-plots of heavy mineral indices for the studied formations (Table 2) and for stratigraphically corresponding formations in Saudi Arabia and Libya. (1) Bassis et al. (2016b), (2) Knox et al. (2007), (3) Morton et al. (2011), (4) Morton et al. (2012).

Figure 10. Comparison of the proportions of amphibolite/eclogite-facies and granulite-facies rutiles and garnets for the two studied formations, respectively, as inferred from Zr-in-rutile thermometry after Tomkins et al. (2007) and the garnet classification scheme after TolosanaDelgado et al. (2018). Large pie charts show the respective total proportions for the whole formation, which are broken down to the single samples in the small pie charts.

Figure 11. Overview over the main findings of this study. Extent and ice flow directions for the Hirnantian ice sheet are after Ghienne et al. (2007), Le Heron and Craig (2008), and Torsvik and Cocks (2013). The contour of Ethiopia is given in red. SMC - Saharan Metacraton, ANS - Arabian-Nubian Shield, MB - Mozambique Belt.

Supplementary Figure 1. Results of rutile chemical analyses displayed for the single samples of the Enticho Sandstone. Left: histograms of the calculated formation temperatures from $\mathrm{Zr}$-in-rutile thermometry; Right: $\mathrm{Cr}-\mathrm{Nb}$ crossplot and pie charts for classification of rutiles derived from metamafic and metafelsic source rocks after Triebold et al. (2012).

Supplementary Figure 2. Results of rutile chemical analyses displayed for the single samples of the Edaga Arbi Glacials. Left: histograms of the calculated formation temperatures from $\mathrm{Zr}$-in-rutile thermometry; Right: $\mathrm{Cr}-\mathrm{Nb}$ crossplot and pie charts for classification of rutiles derived from metamafic and metafelsic source rocks after Triebold et al. (2012).

Supplementary Figure 3. PCA biplot based on the centred log-ratio (clr) transformed concentrations of the endmember-sensitive elements in garnet from the Enticho Sandstone and the Edaga Arbi Glacials. (a) First and second principal component. (b) First and third principal component. 


\begin{tabular}{|c|c|c|c|c|c|c|c|c|c|}
\hline \# & Sample & Formation & Age & Location & North $\left({ }^{\circ}\right)$ & $\operatorname{East}\left({ }^{\circ}\right)$ & $\begin{array}{l}\text { Facies/ } \\
\text { Lithology }\end{array}$ & $\begin{array}{l}\text { Strati- } \\
\text { graphic } \\
\text { assignment }\end{array}$ & Methods \\
\hline 1 & Enti-4 & Enticho & Upper Ordovician & Atsbi south & 13.83465 & 039.71262 & Tillite matrix & $\mathrm{C}$ & $\mathrm{HMA}^{*}-\mathrm{r}$, rtl, grt \\
\hline 2 & Enti-5 & Enticho & Upper Ordovician & Atsbi north & 13.88828 & 039.74783 & Glacial & B & HMA-r, grt \\
\hline 3 & Enti-7 & Enticho & Upper Ordovician & Atsbi north & 13.88842 & 039.74259 & Glacial & $\mathrm{B}$ & HMA-o \\
\hline 4 & Enti-9 & Enticho & Upper Ordovician & Wollwello & 14.22037 & 039.65014 & Glacial & B & HMA-r, grt \\
\hline 5 & Enti-13 & Enticho & Upper Ordovician & Zalambassa & 14.49275 & 039.41911 & Glacial & LF & HMA-r, rtl \\
\hline 6 & $\mathrm{~S} 1$ & Enticho & Upper Ordovician & Sinkata & 13.96861 & 039.61167 & Glacial & $\mathrm{B}$ & HMA-o \\
\hline 7 & $\mathrm{~S} 2$ & Enticho & Upper Ordovician & Sinkata & 13.96861 & 039.61167 & Glacial & $\mathrm{B}$ & HMA-o \\
\hline 8 & Nib-1 & Enticho & Upper Ordovician & Adigrat south & 14.25194 & 039.48972 & Glacial & $\mathrm{B}$ & Rtl \\
\hline 9 & Nib-2 & Enticho & Upper Ordovician & Adigrat south & 14.25194 & 039.48972 & Glacial & $\mathrm{B}$ & HMA-r, grt \\
\hline 10 & North-1 & Enticho & Upper Ordovician & Adigrat north & 14.31333 & 039.46000 & Glacial & $\mathrm{B}$ & HMA-o \\
\hline 11 & North-2 & Enticho & Upper Ordovician & Adigrat north & 14.31333 & 039.46000 & Glacial & $\mathrm{B}$ & HMA-o \\
\hline 12 & Enti-6 & Enticho & Upper Ordovician & Atsbi north & 13.88842 & 039.74827 & Marine & B & HMA-r, rtl \\
\hline 13 & Enti-10 & Enticho & Upper Ordovician & Wollwello & 14.21839 & 039.64994 & Marine & B & HMA-o \\
\hline 14 & Enti-12 & Enticho & Upper Ordovician & Zalambassa & 14.49627 & 039.41911 & Marine & LF & HMA*-r, rtl \\
\hline 15 & S3 & Enticho & Upper Ordovician & Sinkata & 13.97056 & 039.61111 & Marine & B & HMA-o \\
\hline 16 & S4 & Enticho & Upper Ordovician & Sinkata & 13.97056 & 039.61111 & Marine & B & HMA-o \\
\hline 17 & Nib-3 & Enticho & Upper Ordovician & Adigrat south & 14.25222 & 039.49583 & Marine & B & Rtl \\
\hline 18 & Nib-4 & Enticho & Upper Ordovician & Adigrat south & 14.25222 & 039.49583 & Marine & B & HMA-o \\
\hline 19 & North-3 & Enticho & Upper Ordovician & Adigrat north & 14.31944 & 039.45889 & Marine & B & HMA-о \\
\hline 20 & Eda-5 & Enticho & Upper Ordovician & Adwa east & 14.19102 & 038.93957 & Sand lens & $\mathrm{C}$ & HMA-r \\
\hline 21 & Eda-2 & Edaga Arbi & Carboniferous-Permian & Enticho & 14.28166 & 039.14725 & Tillite matrix & B & $\mathrm{HMA}^{*}-\mathrm{r}, \mathrm{rtl}$ \\
\hline 22 & Eda-3 & Edaga Arbi & Carboniferous-Permian & Enticho & 14.27929 & 039.14836 & Sand lens & $\mathrm{C}$ & HMA-r, rtl \\
\hline 23 & Eda-4 & Edaga Arbi & Carboniferous-Permian & Edaga Robi & 14.38906 & 039.18161 & Tillite matrix & $\mathrm{C}$ & HMA-о \\
\hline 24 & Eda-6 & Edaga Arbi & Carboniferous-Permian & Edaga Arbi west & 14.05667 & 039.07095 & Sand lens & LF & HMA-o \\
\hline 25 & Eda-8 & Edaga Arbi & Carboniferous-Permian & Megab south & 13.90944 & 039.32301 & Sand lens & $\mathrm{B}$ & HMA-o \\
\hline 26 & Eda-9 & Edaga Arbi & Carboniferous-Permian & Megab south & 13.90915 & 039.32235 & Sand lens & B & HMA-r, rtl, grt \\
\hline 27 & Eda-10 & Edaga Arbi & Carboniferous-Permian & Dugum & 13.84957 & 039.49003 & Sand lens & LF & HMA-o \\
\hline 28 & Eda-11 & Edaga Arbi & Carboniferous-Permian & Abi Addi & 13.61842 & 039.00042 & Sand lens & LF & HMA-r, rtl, grt \\
\hline 29 & Eda-12 & Edaga Arbi & Carboniferous-Permian & Samre & 13.17844 & 039.19745 & Sand lens & B & HMA-r, grt \\
\hline 30 & $\mathrm{Hu}-1$ & Edaga Arbi & Carboniferous-Permian & Bure, Blue Nile & 10.31057 & 037.05068 & Sand lens & LF & HMA*-r, grt \\
\hline 31 & Hu-2 & Edaga Arbi & Carboniferous-Permian & Bure, Blue Nile & 10.31057 & 037.05068 & Sand lens & LF & HMA-r, grt \\
\hline
\end{tabular}

Table 1. 


\begin{tabular}{llrrrrr} 
Sample & Formation & ZTR & RZi & \multicolumn{1}{c}{ GZi } & \multicolumn{1}{c}{ ATi } & STi \\
\hline Enti-4* & Enticho Sandstone & 22.4 & 25.0 & 84.5 & 61.9 & 0.0 \\
Enti-5* & Enticho Sandstone & 49.5 & 19.3 & 56.3 & 0.0 & 23.9 \\
Enti-6* & Enticho Sandstone & 86.2 & 22.9 & 0.0 & 0.0 & 23.1 \\
Enti-7 & Enticho Sandstone & 82.5 & 20.3 & 16.2 & 8.3 & 24.1 \\
Enti-9* & Enticho Sandstone & 70.1 & 45.7 & 49.0 & 0.0 & 11.8 \\
Enti-10 & Enticho Sandstone & 90.5 & 31.5 & 0.0 & 5.4 & 2.8 \\
Enti-12* & Enticho Sandstone & 99.9 & 10.8 & 0.1 & 0.0 & 0.0 \\
Enti-13* & Enticho Sandstone & 94.9 & 10.1 & 0.2 & 0.0 & 0.0 \\
S1 & Enticho Sandstone & 67.9 & 14.3 & 6.7 & 30.3 & 30.3 \\
S2 & Enticho Sandstone & 79.0 & 17.9 & 2.8 & 60.0 & 9.1 \\
S3 & Enticho Sandstone & 85.1 & 20.2 & 3.7 & 12.5 & 22.2 \\
S4 & Enticho Sandstone & 86.0 & 12.6 & 1.0 & 0.0 & 23.2 \\
Nib-2* & Enticho Sandstone & 87.6 & 29.2 & 16.2 & 0.0 & 0.0 \\
Nib-4 & Enticho Sandstone & 91.2 & 35.4 & 0.0 & 4.5 & 4.5 \\
Nord-1 & Enticho Sandstone & 85.0 & 12.4 & 13.0 & 0.0 & 10.0 \\
Nord-2 & Enticho Sandstone & 74.5 & 15.6 & 26.0 & 0.0 & 0.0 \\
Nord-3 & Enticho Sandstone & 86.5 & 22.4 & 3.2 & 0.0 & 15.0 \\
Eda-2* & Edaga Arbi Glacials & 21.7 & 33.3 & 4.0 & 88.6 & 1.6 \\
Eda-3* & Edaga Arbi Glacials & 32.5 & 40.7 & 0.0 & 81.7 & 0.0 \\
Eda-4 & Edaga Arbi Glacials & 23.0 & 26.3 & 54.8 & 83.5 & 0.0 \\
Eda-5* & Enticho? & 96.2 & 12.7 & 0.0 & 20.7 & 4.4 \\
Eda-6 & Edaga Arbi Glacials & 4.0 & 50.0 & 96.6 & 87.5 & 0.0 \\
Eda-8 & Edaga Arbi Glacials & 6.0 & 37.5 & 91.9 & 97.0 & 0.0 \\
Eda-9* & Edaga Arbi Glacials & 31.1 & 64.4 & 72.8 & 77.5 & 2.3 \\
Eda-10 & Edaga Arbi Glacials & 6.5 & 23.1 & 94.5 & 100.0 & 0.0 \\
Eda-11* & Edaga Arbi Glacials & 10.8 & 47.4 & 93.3 & 93.9 & 0.0 \\
Eda-12* & Edaga Arbi Glacials & 5.1 & 92.3 & 98.2 & 99.3 & 0.0 \\
Hu-1* & Edaga Arbi Glacials & 4.3 & 16.0 & 95.8 & 97.1 & 0.0 \\
Hu-2* & Edaga Arbi Glacials & 2.4 & 0.0 & 95.3 & 99.2 & 0.0 \\
& & & & & & \\
Enticho mean & 79.7 & 20.4 & 17.3 & 14.6 & 14.4 \\
Edaga Arbi mean & 13.4 & 43.0 & 88.3 & 88.7 & 0.9 \\
& & & & & &
\end{tabular}

Table 2. 


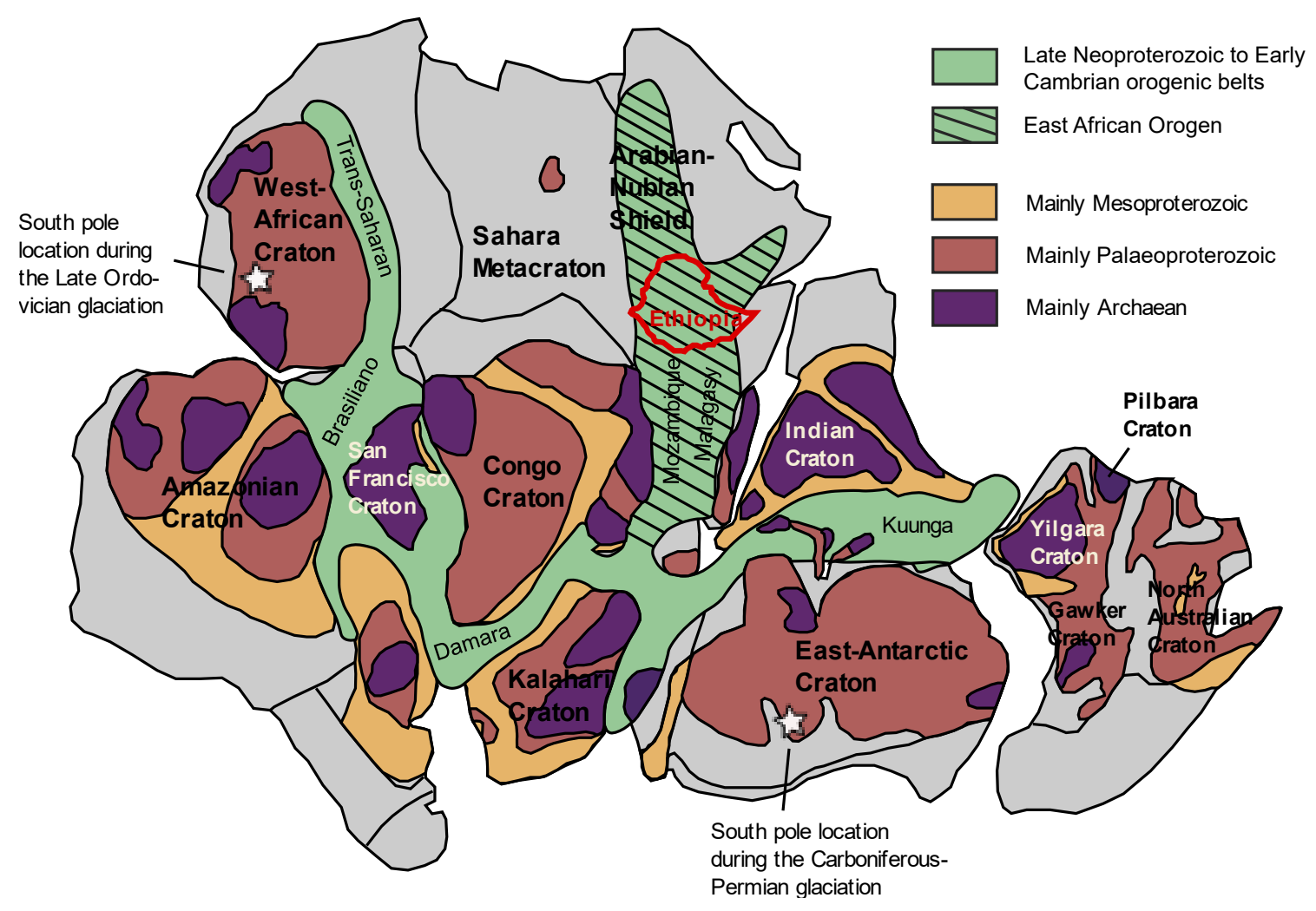

Figure 1. 


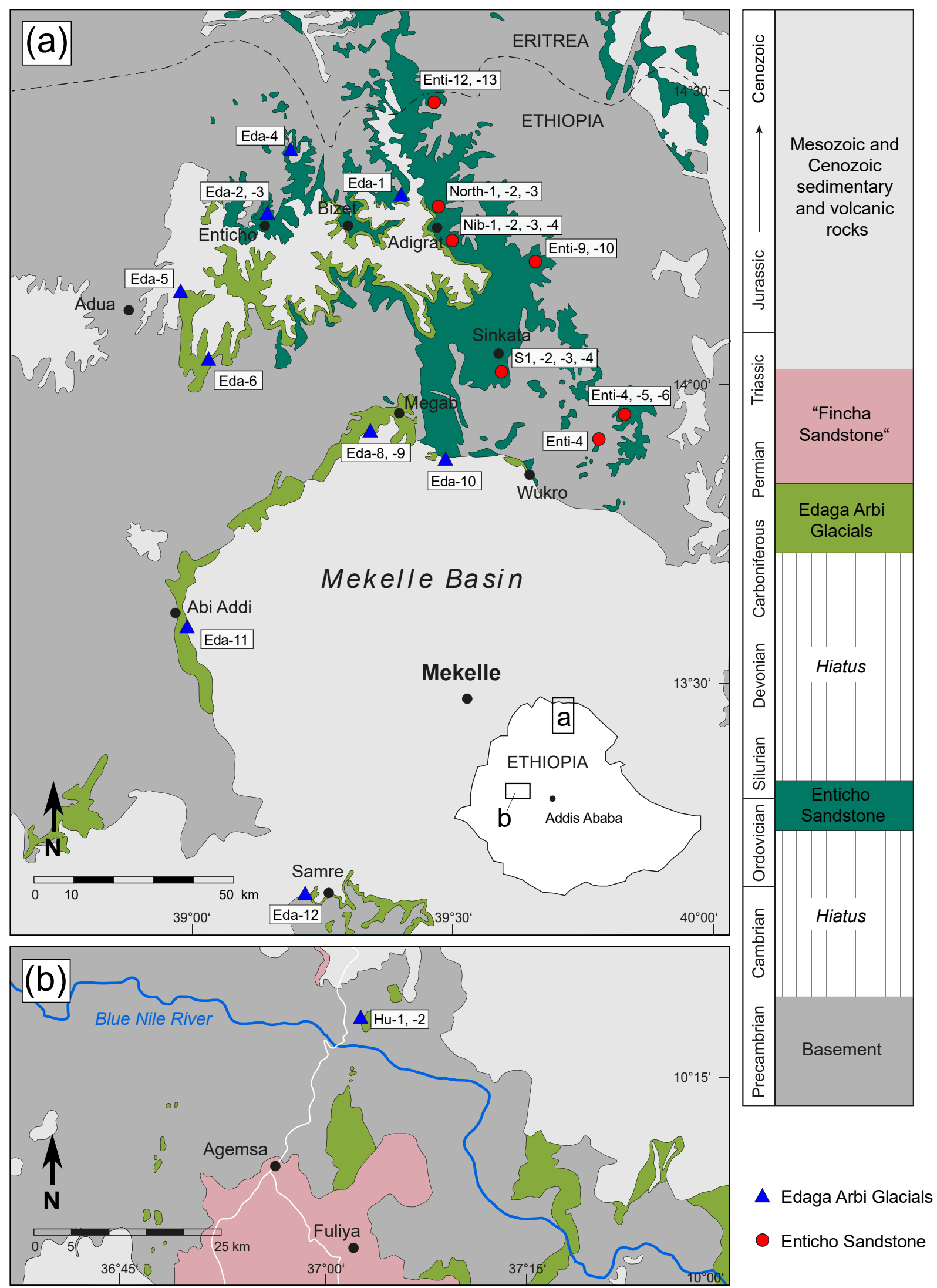

Figure 2. 


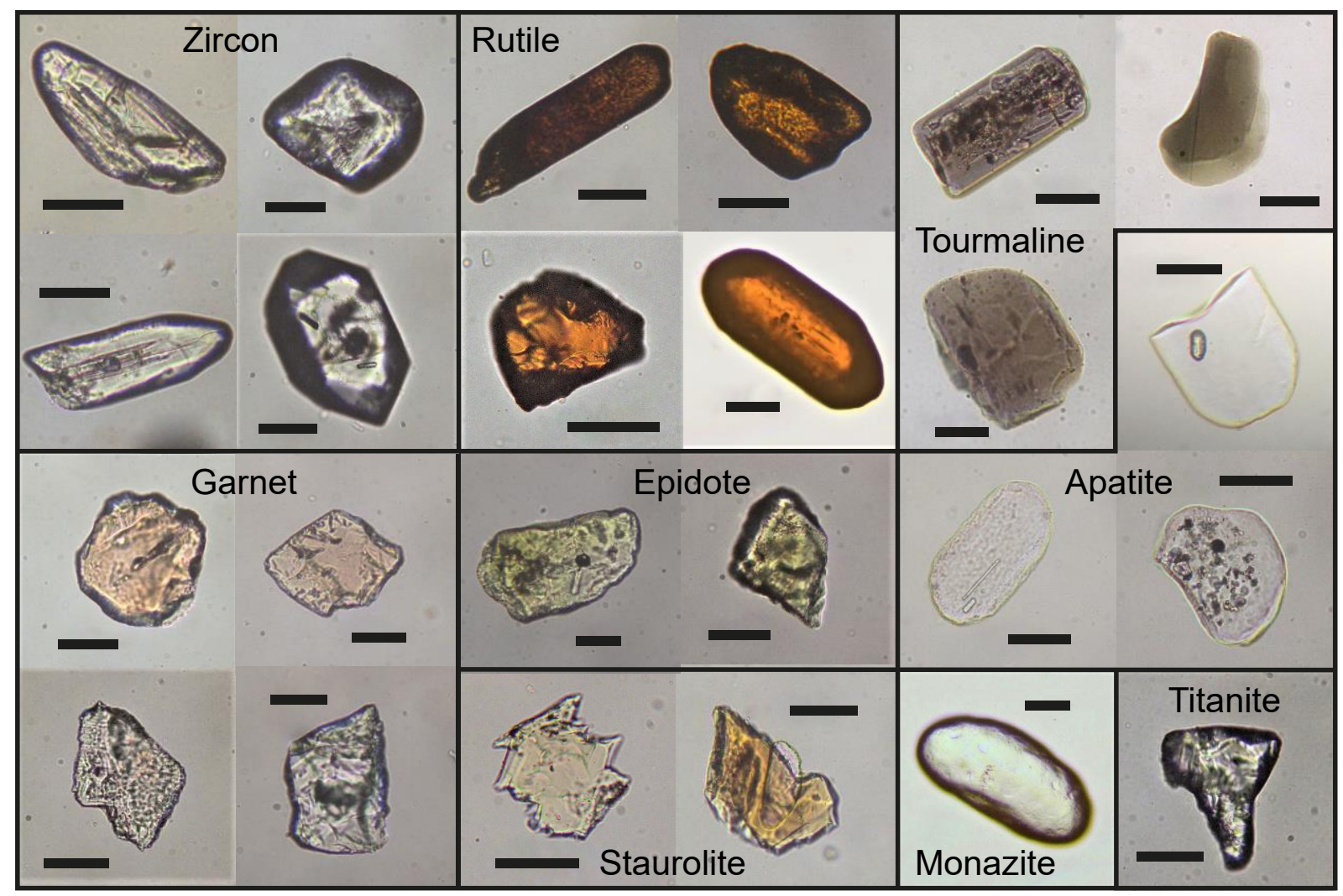

Figure 3.

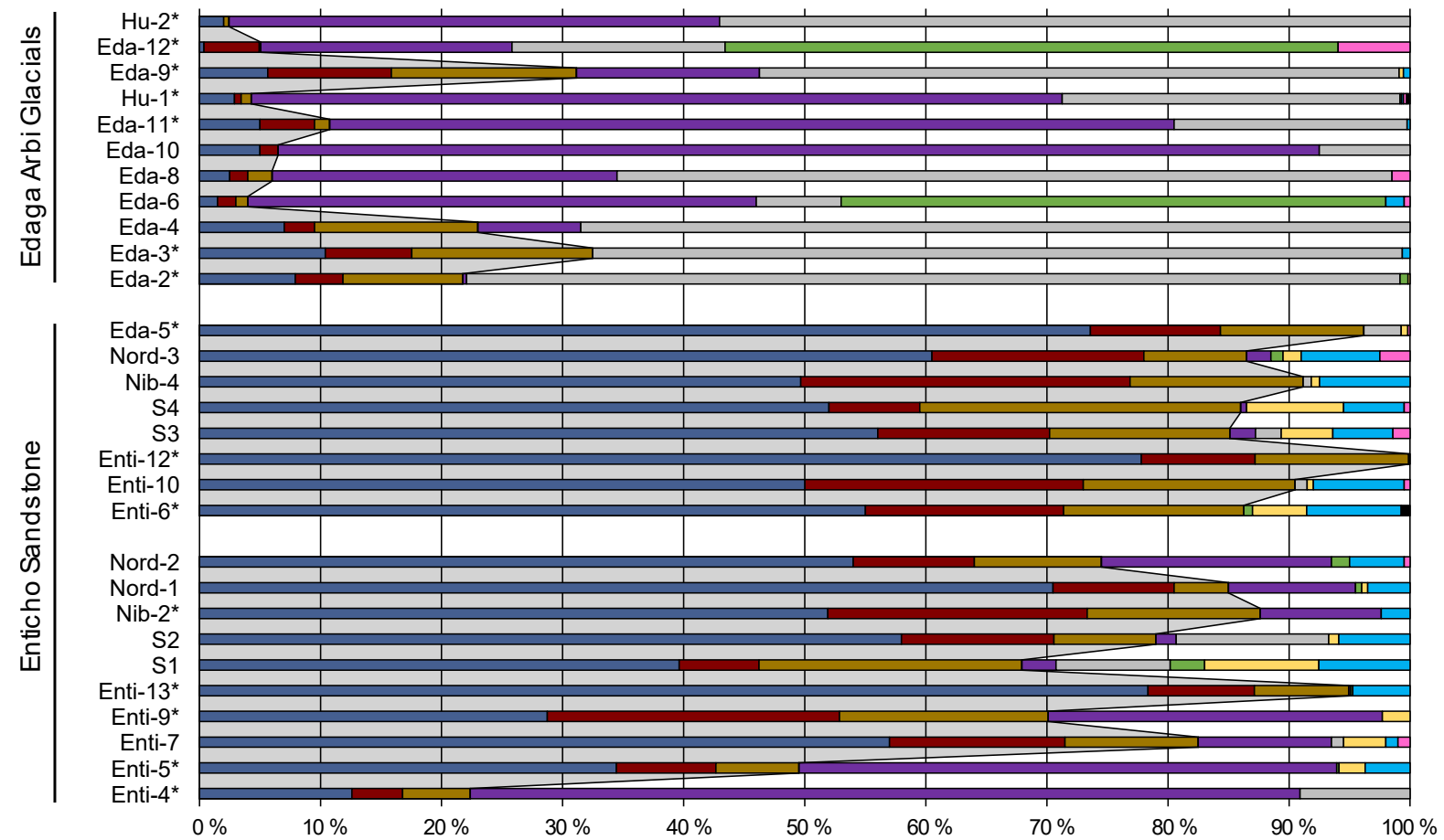

$\square$ Zircon $\square$ Rutile $\square$ Tourmaline $\square$ Garnet $\square$ Apatite $\square$ Epidote Group $\square$ Staurolite $\square$ Monazite $\square$ Titanite $\square$ Others

Figure 4. 


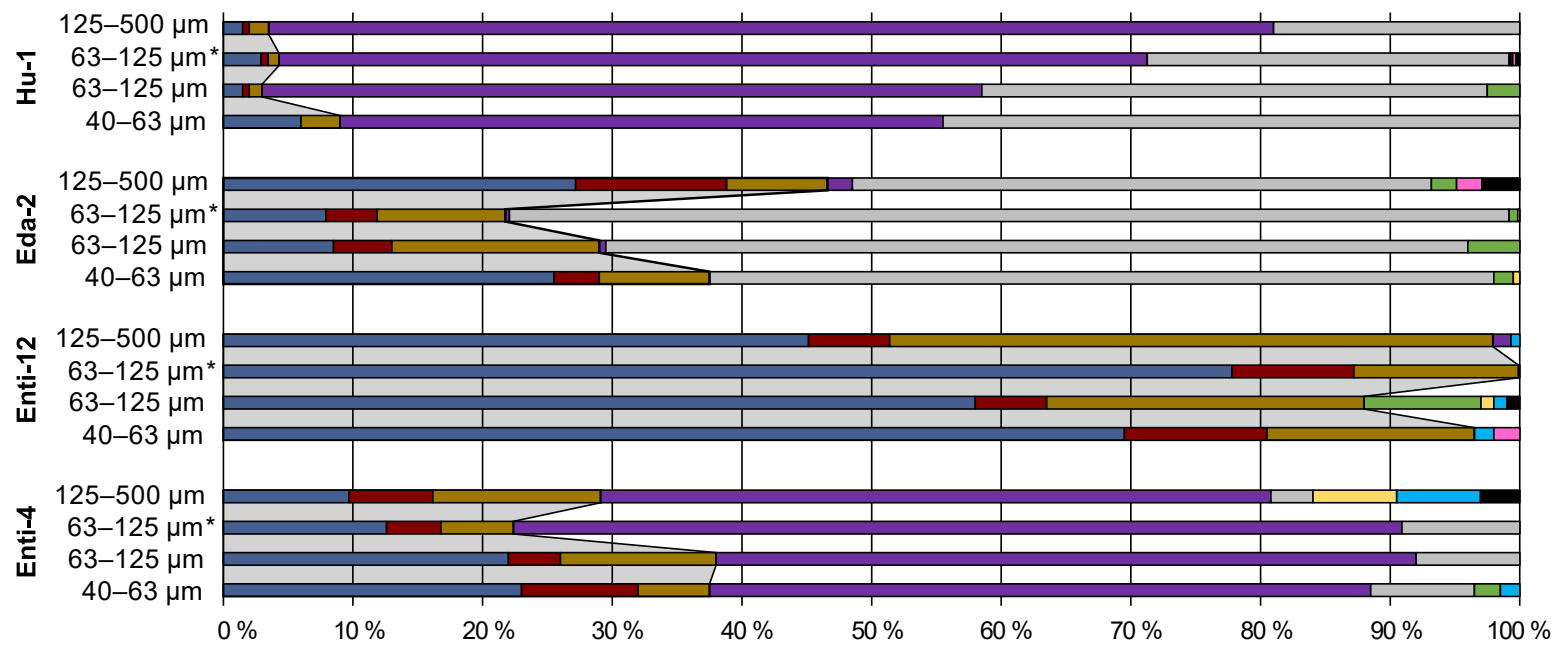

$\square$ Zircon $\square$ Rutile $\square$ Tourmaline $\square$ Garnet $\square$ Apatite $\square$ Epidote Group $\square$ Staurolite $\square$ Monazite $\square$ Titanite $\square$ Other

\section{Figure 5.}

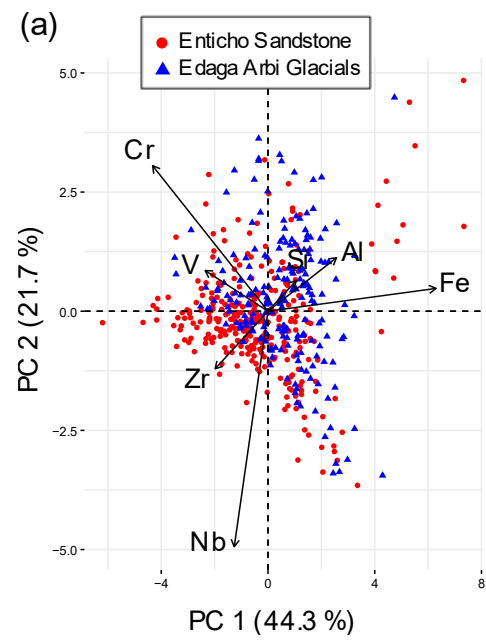

(b)

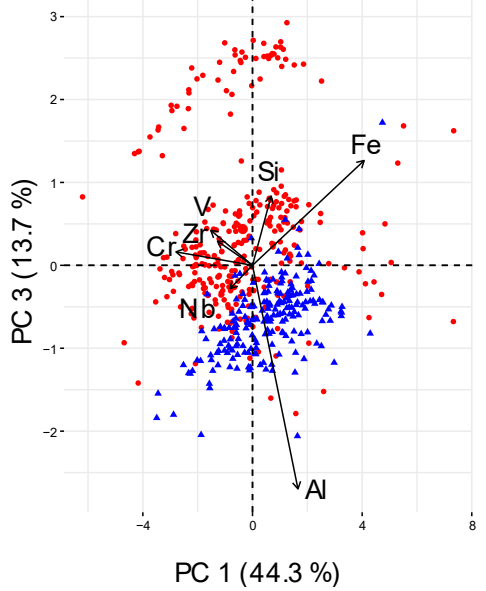

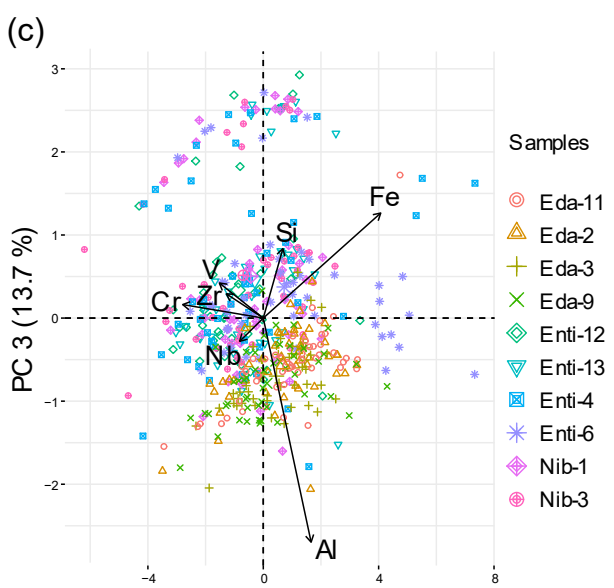

PC 1 (44.3\%)

Figure 6. 
(a) Enticho Sandstone $(n=282)$
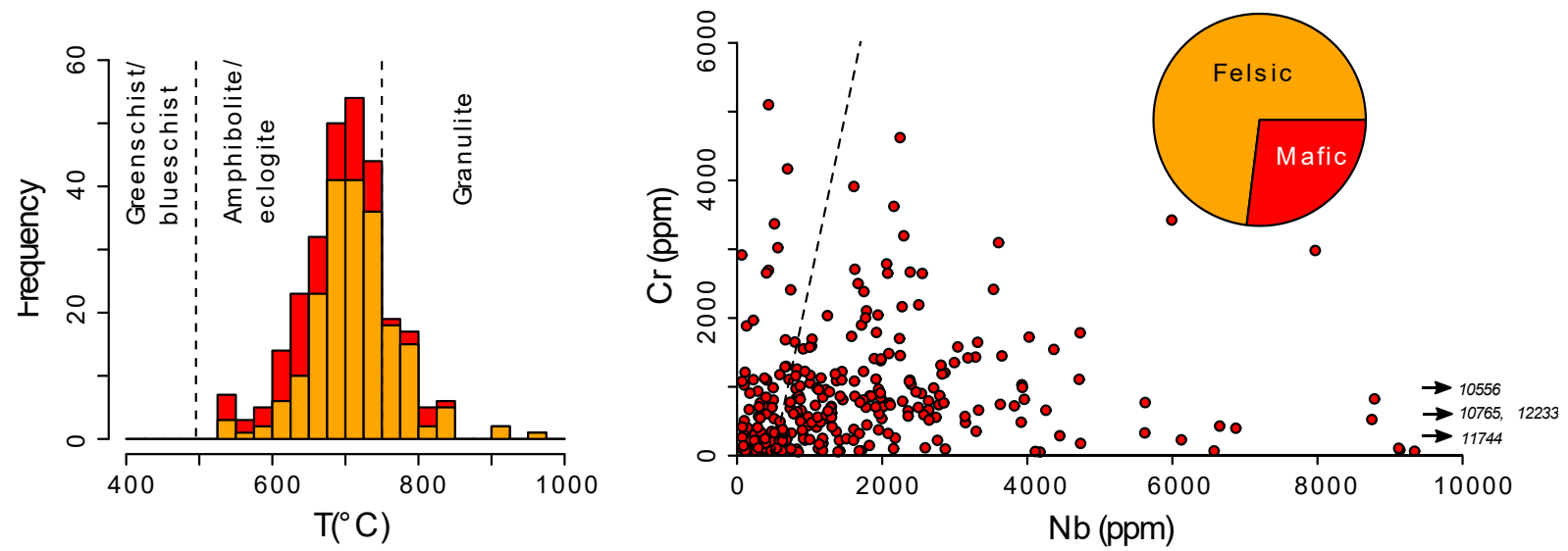

(b) Edaga Arbi Glacials $(n=171)$
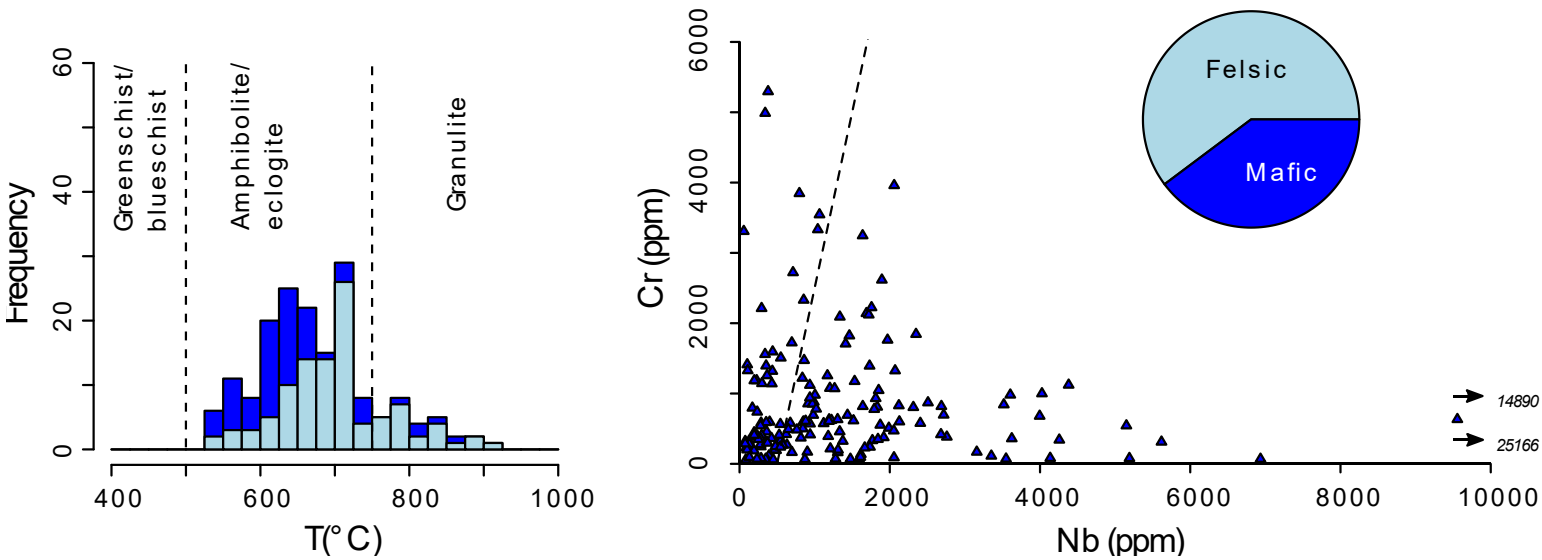

Figure 7.

(a) Enticho Sandstone

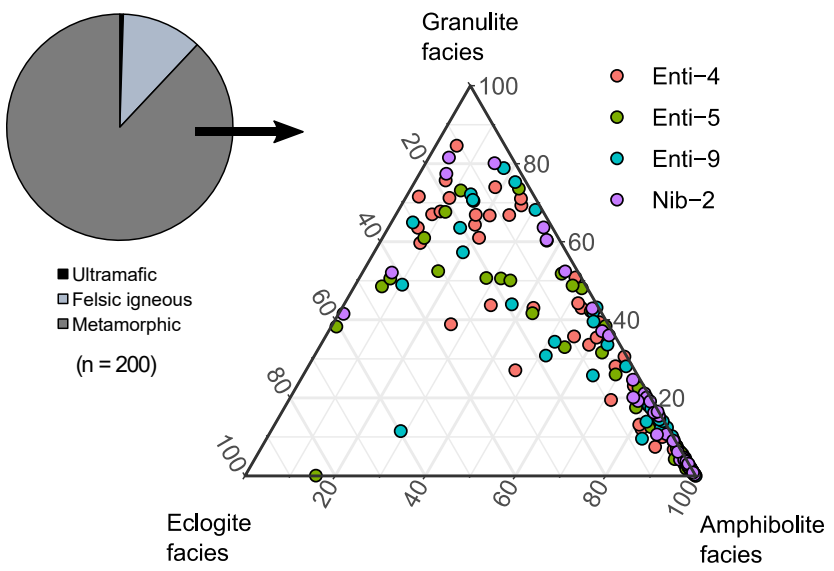

(b) Edaga Arbi Glacials

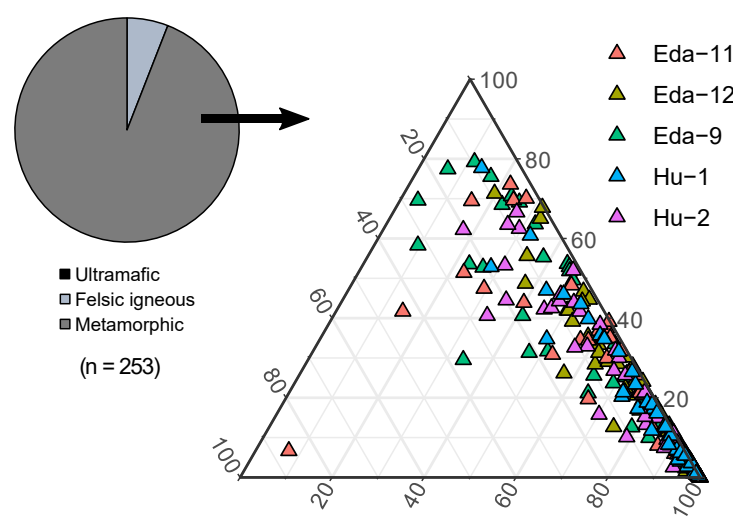

Figure 8. 

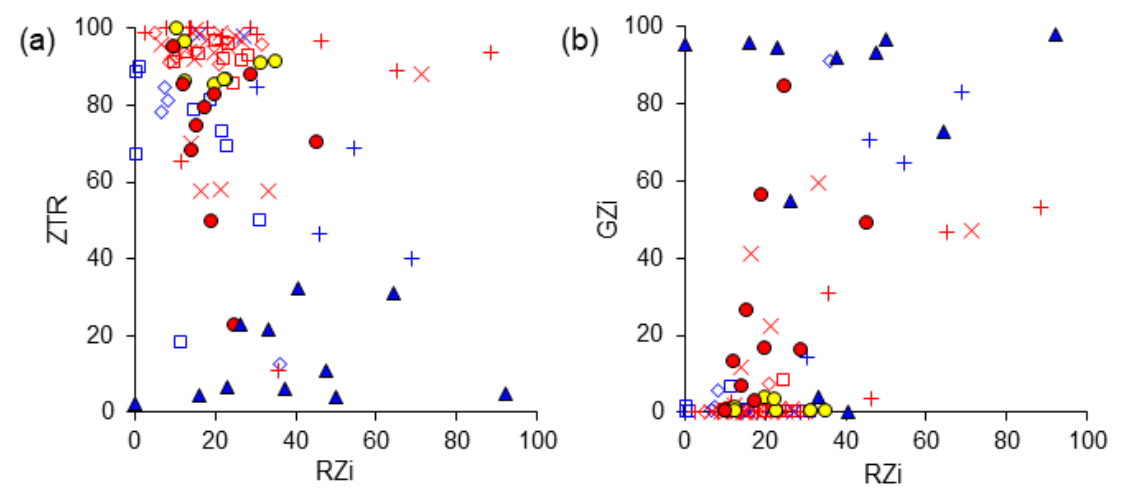

$\Delta$ Edaga Arbi

- Enticho marine

- Enticho glaciogenic

$\diamond$ Saudi Arabia, Carb.-Perm. (1)

口Saudi Arabia, Carb.-Perm. (2)

$\checkmark$ Saudi Arabia, Ord.-Sil. (1)

$\square$ Saudi Arabia, Ord.-Sil. (2)

+ Libya, Carb.-Perm. (3)

(c)

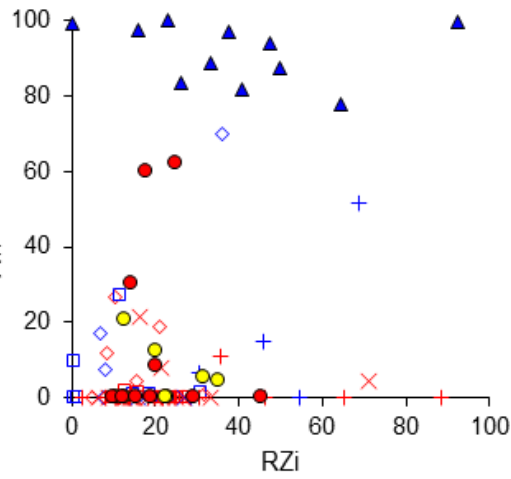

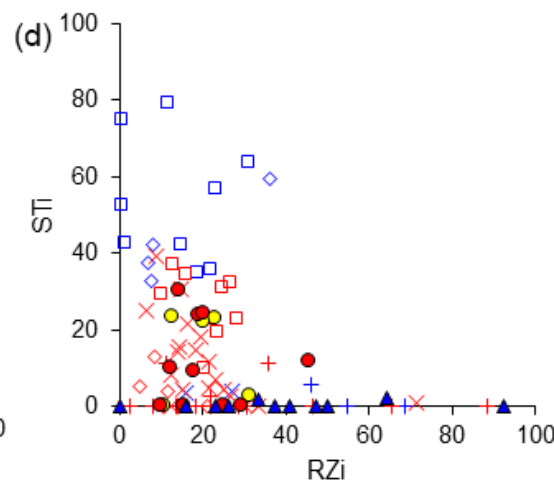

$\times$ Libya, Carb.-Perm. (4)

+ Libya, Ord.-Sil. (3)

$\times$ Libya, Ord.-Sil. (4)

Figure 9.

Enticho Sandstone
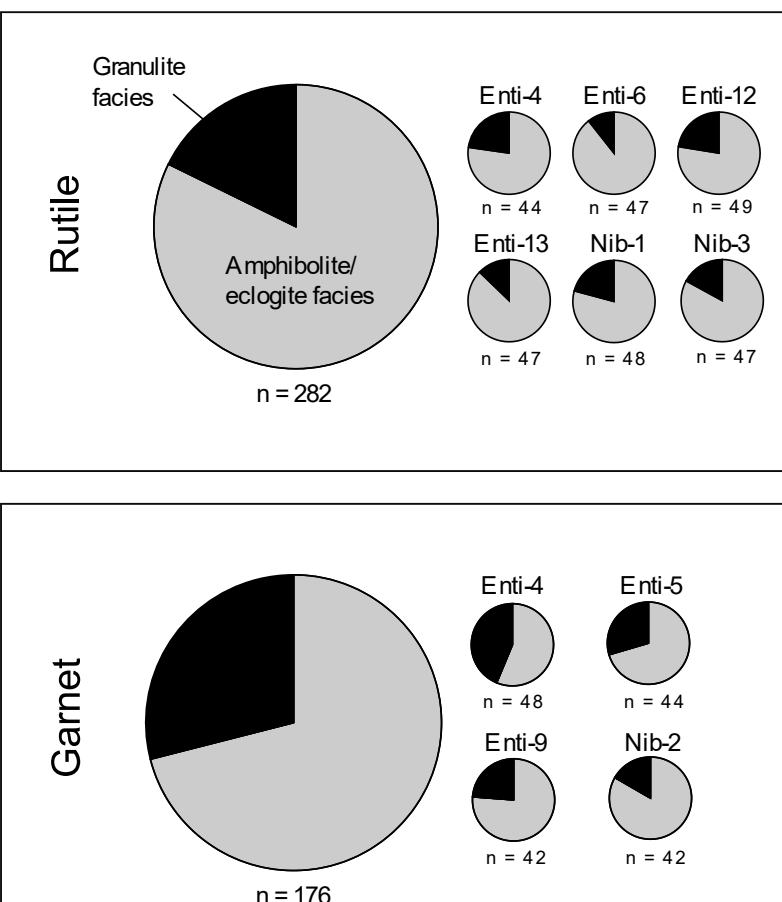

Edaga Arbi Glacials
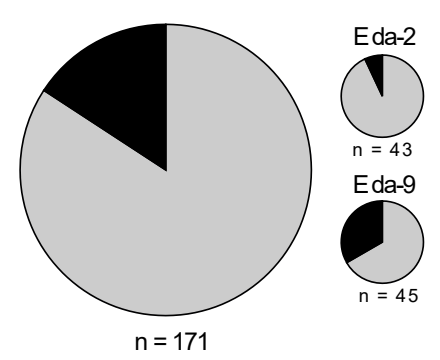

Eda-3

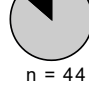

Eda-11

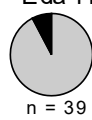

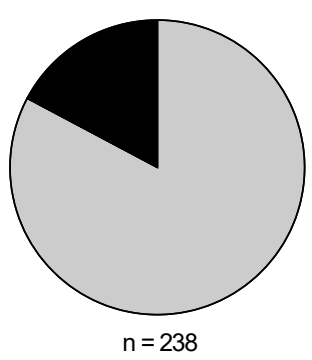
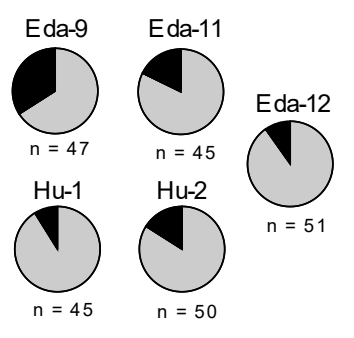

Figure 10. 


\section{Late Ordovician}

Direction of ice flow within the Himantian ice sheet

Direction of sediment Direction of sediment
transport based on the results of this study

$\square$ Study areas

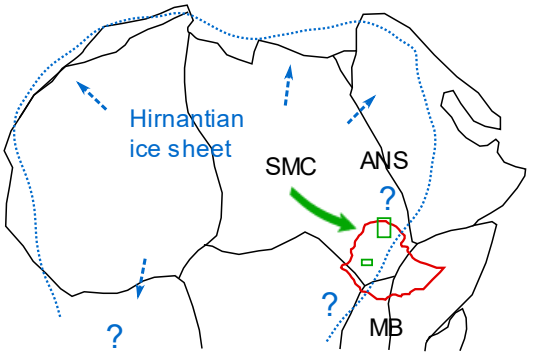

\section{Enticho Sandstone}

Heavy mineral assemblage

Rutile and garnet metamorphic temperatures

Inferred source

Mainly recycled/reworked Cambrian-Ordovician sediments ("super-fan sediments"); variable admixture of fresh basement material from the

Sahara Metacraton or the Arabian-Nubian Shield

\section{Carboniferous-Permian}

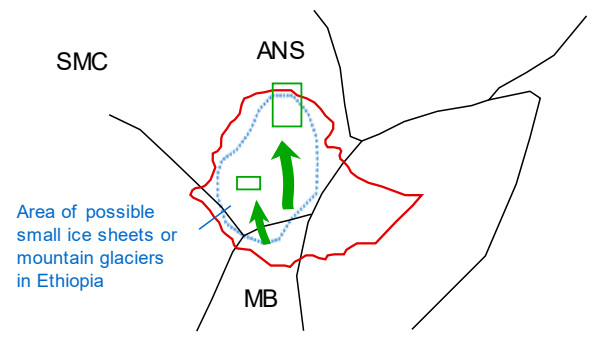

\section{Edaga Arbi Glacials}

Dominated by garnet and apatite, locally epidote

Amphibolite facies, to a lesser extent granulite facies

Basement rocks of the southern Arabian-Nubian Shield at the transition to the Mozambique Belt

Figure 11. 

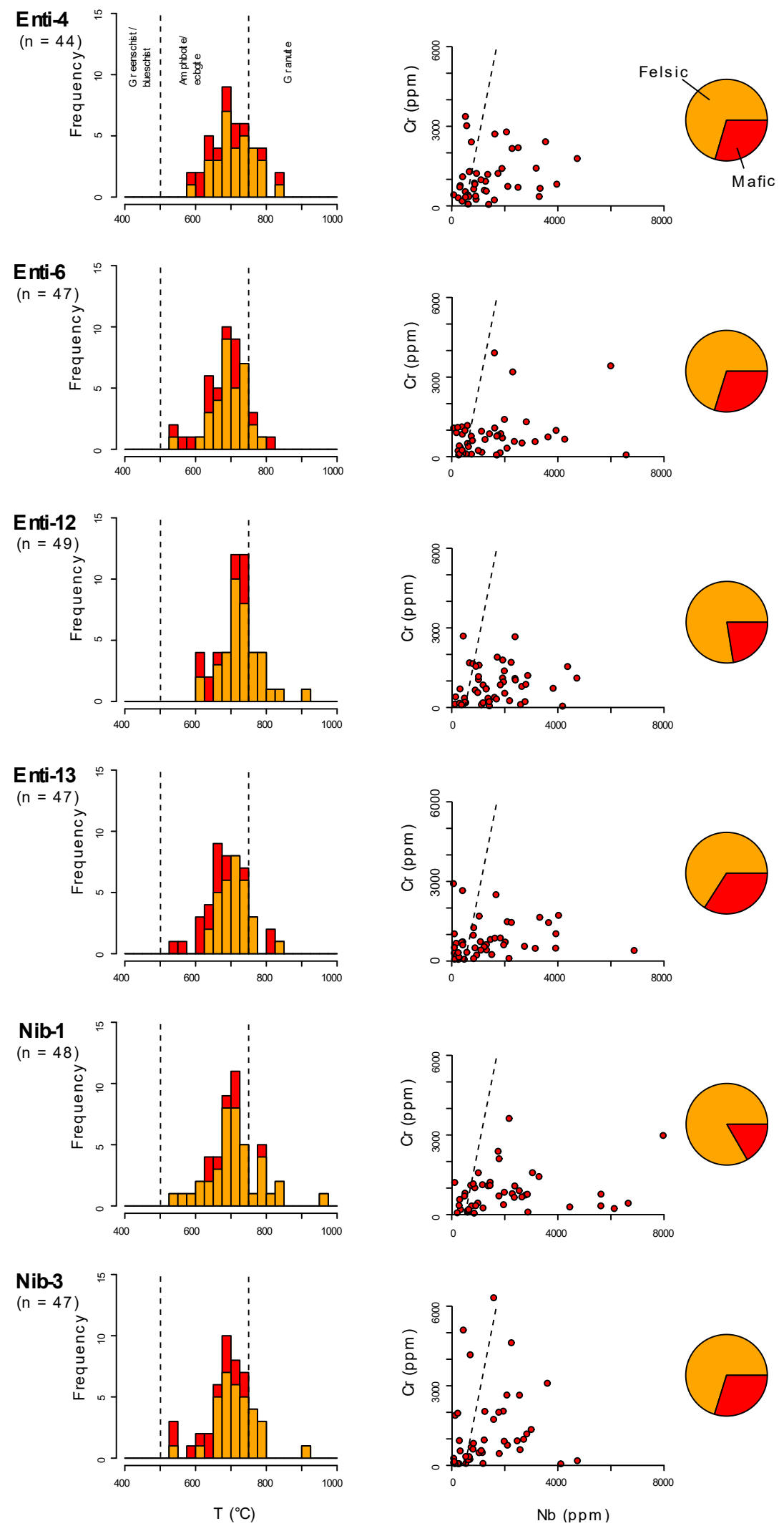

Supplementary Figure 1 

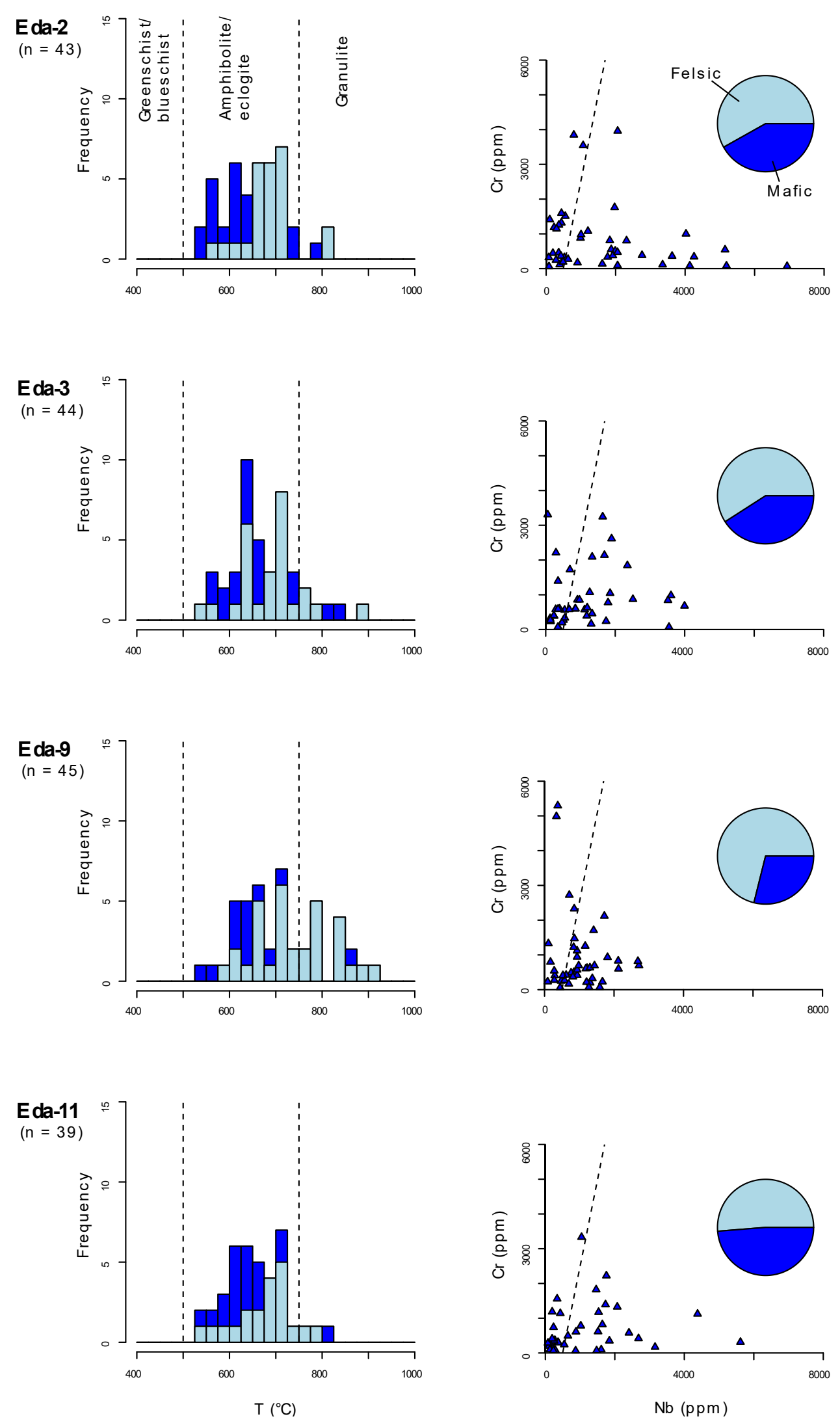

Supplementary Figure 2. 
(a)

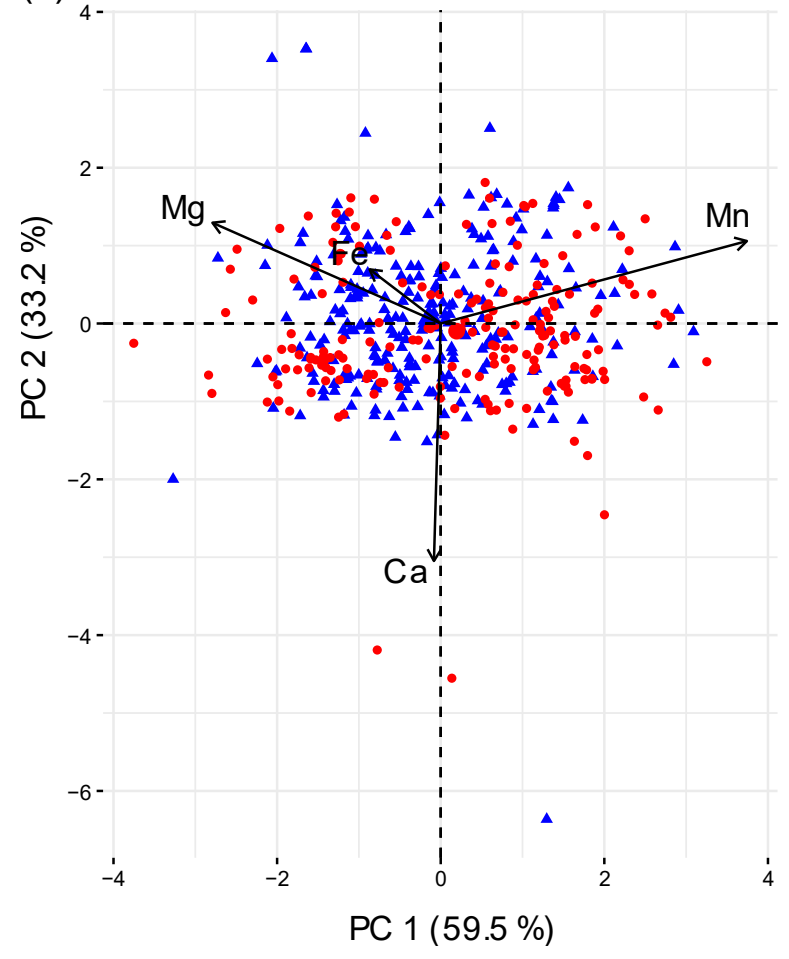

(b)

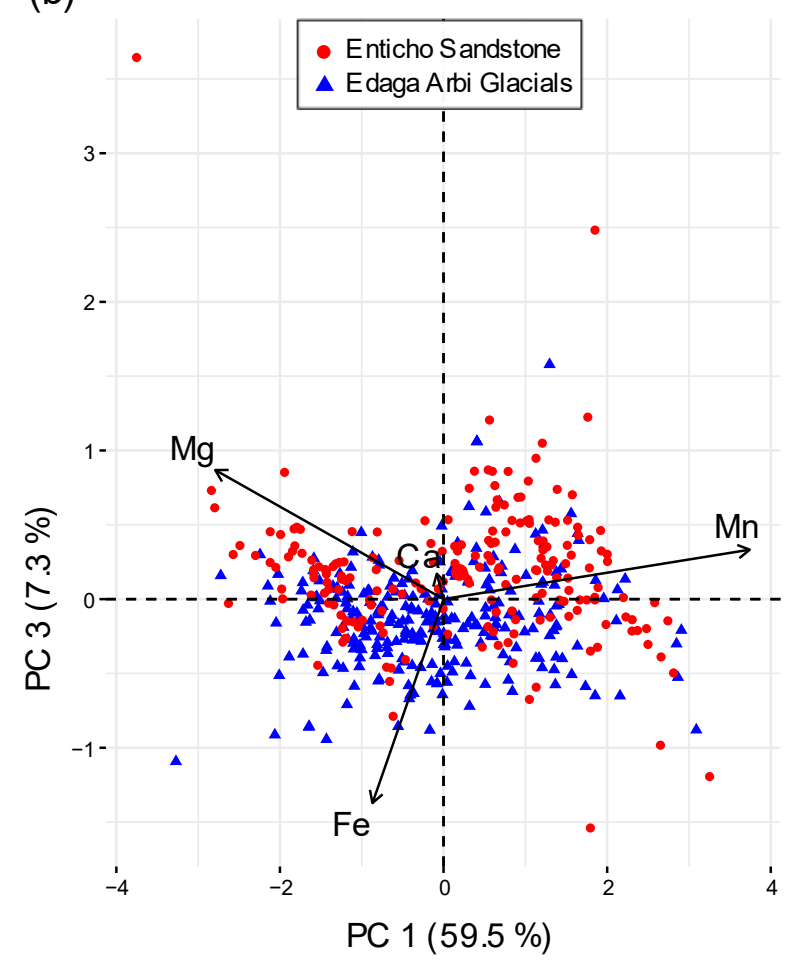

Supplementary Figure 3. 